\title{
Photosynthetic performance and stevioside concentration are improved by the arbuscular mycorrhizal symbiosis in Stevia rebaudiana under different phosphate concentrations
}

\author{
Luis G Sarmiento-López ${ }^{1}$, Melina López-Meyer ${ }^{2}$, Gabriela Sepúlveda-Jiménez ${ }^{1}$, Luis Cárdenas ${ }^{3}$, Mario Rodríguez \\ Monroy ${ }^{\text {Corresp. } 1}$ \\ 1 Departamento de Biotecnología, Centro de Desarrollo de Productos Bióticos-Instituto Politécnico Nacional, Yautepec, Morelos, México
2 Departamento de Biotecnología Agrícola, Centro Interdisciplinario de Investigación para el Desarrollo Integral Regional Unidad Sinaloa-Instituto
Politécnico Nacional, Guasave, Sinaloa, México
3 Departamento de Biología Molecular de Plantas, Instituto de Biotecnología-Universidad Nacional Autónoma de México, Cuernavaca, Morelos, México \\ Corresponding Author: Mario Rodríguez Monroy \\ Email address: mrmonroy@ipn.mx
}

In plants, phosphorus (P) uptake occurs via arbuscular mycorrhizal (AM) symbiosis and through plant roots. The phosphate concentration is known to affect colonization by AM fungi, and the effect depends on the plant species. Stevia rebaudiana plants are valuable sources of sweetener compounds called steviol glycosides (SGs), and the principal components of SGs are stevioside and rebaudioside A. However, a detailed analysis describing the effect of the phosphate concentration on the colonization of AM fungi in the roots and the relationship of these factors to the accumulation of SGs and photochemical performance has not been performed; such an analysis was the aim of this study. The results indicated that low phosphate concentrations (20 and $200 \mu \mathrm{M} \mathrm{KH}_{2} \mathrm{PO}_{4}$ ) induced a high percentage of colonization by Rhizophagus irregularis in the roots of $S$. rebaudiana, while high phosphate concentrations (500 and $1000 \mu \mathrm{M} \mathrm{KH}_{2} \mathrm{PO}_{4}$ ) reduced colonization. The morphology of the colonization structure is a typical Arum-type mycorrhiza, and a mycorrhiza-specific phosphate transporter was identified. Colonization with low phosphate concentrations improved plant growth, chlorophyll and carotenoid concentration, and photochemical performance. The transcription of the genes that encode kaurene oxidase and glucosyltransferase (UGT74G1) was upregulated in colonized plants at $200 \mu \mathrm{M} \mathrm{KH}_{2} \mathrm{PO}_{4}$, which was consistent with the observed patterns of stevioside accumulation. In contrast, at $200 \mu \mathrm{M} \mathrm{KH}_{2} \mathrm{PO}_{4}$, the transcription of UGT76G1 and the accumulation of rebaudioside $\mathrm{A}$ were higher in noncolonized plants than in colonized plants. The results indicate that a low phosphate concentration improves mycorrhizal colonization and modulates the stevioside and rebaudioside $A$ concentration by regulating the transcription of the genes that encode kaurene oxidase and glucosyltransferases, which are involved in stevioside and 
rebaudioside A synthesis in S. rebaudiana. 
1 Photosynthetic performance and stevioside

2 concentration are improved by the arbuscular

3 mycorrhizal symbiosis in Stevia rebaudiana under

4 different phosphate concentrations

5

6 Luis Gerardo Sarmiento-López ${ }^{1}$, Melina López-Meyer ${ }^{2}$, Gabriela Sepúlveda-Jiménez ${ }^{1}$, Luis

7 Cárdenas ${ }^{3}$ and Mario Rodríguez-Monroy ${ }^{1 *}$.

8

$9 \quad{ }^{1}$ Departamento de Biotecnología, Centro de Desarrollo de Productos Bióticos-Instituto

10 Politécnico Nacional, Yautepec, Morelos, México

$11{ }^{2}$ Departamento de Biotecnología Agrícola, Centro Interdisciplinario de Investigación para el

12 Desarrollo Integral Regional Unidad Sinaloa-Instituto Politécnico Nacional, Guasave, Sinaloa, 13 México

$14{ }^{3}$ Departamento de Biología Molecular de Plantas, Instituto de Biotecnología-Universidad

15 Nacional Autónoma de México, Cuernavaca, Morelos, México

Corresponding Author:

18 Mario Rodríguez-Monroy

19 Departamento de Biotecnología, Instituto Politécnico Nacional, Centro de Desarrollo de

20 Productos Bióticos, Yautepec, Morelos, México

21 Email address: mrmonroy@ipn.mx 
41

42

43

44

45

46

47

48

49

50

51

52

53

54

55

56

57

58

59

60

61

62

63

64

65

66

67

68

69

70

71

72

73

74

75

76

77

78

79

80

\section{Abstract}

In plants, phosphorus (P) uptake occurs via arbuscular mycorrhizal (AM) symbiosis and through plant roots. The phosphate concentration is known to affect colonization by AM fungi, and the effect depends on the plant species. Stevia rebaudiana plants are valuable sources of sweetener compounds called steviol glycosides (SGs), and the principal components of SGs are stevioside and rebaudioside A. However, a detailed analysis describing the effect of the phosphate concentration on the colonization of AM fungi in the roots and the relationship of these factors to the accumulation of SGs and photochemical performance has not been performed; such an analysis was the aim of this study. The results indicated that low phosphate concentrations (20 and $200 \mu \mathrm{M} \mathrm{KH}_{2} \mathrm{PO}_{4}$ ) induced a high percentage of colonization by Rhizophagus irregularis in the roots of $S$. rebaudiana, while high phosphate concentrations (500 and $\left.1000 \mu \mathrm{M} \mathrm{KH}_{2} \mathrm{PO}_{4}\right)$ reduced colonization. The morphology of the colonization structure is a typical Arum-type mycorrhiza, and a mycorrhiza-specific phosphate transporter was identified. Colonization with low phosphate concentrations improved plant growth, chlorophyll and carotenoid concentration, and photochemical performance. The transcription of the genes that encode kaurene oxidase and glucosyltransferase ( $U G T 74 G 1)$ was upregulated in colonized plants at $200 \mu \mathrm{M} \mathrm{KH}_{2} \mathrm{PO}_{4}$, which was consistent with the observed patterns of stevioside accumulation. In contrast, at $200 \mu \mathrm{M}$ $\mathrm{KH}_{2} \mathrm{PO}_{4}$, the transcription of $U G T 76 G 1$ and the accumulation of rebaudioside A were higher in noncolonized plants than in colonized plants. The results indicate that a low phosphate concentration improves mycorrhizal colonization and modulates the stevioside and rebaudioside A concentration by regulating the transcription of the genes that encode kaurene oxidase and glucosyltransferases, which are involved in stevioside and rebaudioside A synthesis in $S$. rebaudiana.

\section{Introduction}

Stevia rebaudiana Bertoni is a plant that belongs to the Asteraceae family and accumulates compounds in its leaves called steviol glycosides (SGs) (Brandle, Starratt \& Gijzen, 1998). Stevioside and rebaudioside A are the best-known SGs and are important compounds for human health because they are natural low-calorie sweeteners. The sweetening power of stevioside and rebaudioside $\mathrm{A}$ is 143 and 320 times higher than that of sucrose, respectively (Lemus-Mondaca et al., 2012; Brandle \& Telmer, 2007). The biosynthetic pathway for SG synthesis begins in the chloroplasts with the synthesis of geranylgeranyl diphosphate (GGDP) generated from the MEP (methyl-erythritol-4-phosphate) pathway (Totté et al., 2000). GGDP is transformed to kaurene by two cyclization steps carried out by a terpene cyclase (Brandle \& Telmer, 2007). In the endoplasmic reticulum, kaurene is oxidized by kaurene oxidase (KO) to kaurenoic acid; the oxidation of kaurenoic acid produces gibberellins, while the hydroxylation of kaurenoic acid produces steviol. The hydroxyl groups of steviol are glycosylated by the enzymes uridine 
81 diphosphate (UDP)-glycosyltransferases (UGTs), and the number of sugars attached by UGTs 82 generates the various SGs (Brandle \& Telmer, 2007). The UGT74G1 enzyme is involved in the 83 conversion of steviolbioside to stevioside, while the UGT76G1 enzyme converts stevioside into 84 rebaudioside A (Kim et al., 2019).

85

86

87

88

89

90

91

92

93

94

95

96

97

98

99

100

101

102

103

104

105

106

107

108

109

110

111

112

113

114

115

116

117

118

119

120

Arbuscular mycorrhizal (AM) symbiosis between the phylum Glomeromycota and plants is a mutualistic association that is useful in the culture of plants and has agricultural and medicinal importance. This symbiosis improves plant growth, photosynthesis and nutrient uptake and increases the production of phytochemicals (Smith \& Read, 2008; Spatafora et al., 2016; Schoefs et al., 2015).

In plants, there are two modes of P uptake: one mode is by the plant's own Pi transporters, and the other mode occurs via AM symbiosis with mycorrhiza-specific phosphate transporters and takes place in the arbuscules (Harrison, Dewbre \&Liu, 2002). Phosphate transporters are considered a key feature of this mycorrhizal symbiosis (Karandashov \& Bucher, 2005). Mycorrhiza-specific phosphate transporters are expressed in arbuscule-containing cortical root cells and are thus considered general markers for AM symbiosis in different model plants (Harrison, Dewbre \& Liu, 2002; Nagy et al., 2005; Nouri et al., 2014). Likewise, the phosphate concentration affects the colonization of roots by AM. Phosphate application at a high concentration may inhibit the formation of arbuscular mycorrhizae, and the sensitivity to phosphate and the grade of inhibition of arbuscule formation depend on the plant species (Smith, Smith \& Jakobsen, 2004); for example, these factors differ in Medicago truncatula (Bonneau et al., 2013) and Petunia hybrida (Breuillin et al., 2010; Nouri et al., 2014).

In S. rebaudiana, AM symbiosis enhances the production of stevioside and rebaudioside A and involves nutritional and nonnutritional mechanisms (Mandal et al., 2013). AM symbiosis also upregulates the transcription of eleven SG biosynthesis genes as a consequence of the improved nutrition status and the increase in photosynthesis in the plant (Mandal et al., 2015). This result suggests the roles of phosphorus nutrition and $\mathrm{AM}$ symbiosis in influencing $\mathrm{SG}$ concentration; fertilization with $25 \mathrm{mg} \mathrm{P}_{2} \mathrm{O}_{5} \mathrm{~kg}^{-1}$ soil in association with AM symbiosis improved $\mathrm{SG}$ yield, $\mathrm{P}$ uptake and P nutrient use efficiency (Tavarini et al., 2018). However, a detailed analysis and systematic description of the morphological type of AM symbiosis and the effect of the different phosphate concentrations on the establishment of AM symbiosis, the identification of mycorrhiza-specific phosphate transporters, the photosynthetic performance, and the relationship with the accumulation of SGs in S. rebaudiana plants have not been addressed. Therefore, in this study, we reported the effects of different phosphate concentrations on the establishment of AM symbiosis between Rhizophagus irregularis and S. rebaudiana, their relationship with photochemical performance and the accumulation of steviol glycosides (SGs) and the expression of two key genes, $U G T 74 G 1$ and $U G T 76 G 1$, which encode the (UDP)-glycosyltransferases involved in stevioside and rebaudioside A biosynthesis, respectively. The participation of a

Peer) reviewing PDF | (2020:07:50625:2:0:NEW 8 Sep 2020) 
121 mycorrhiza-specific phosphate transporter as a key feature of this mycorrhizal symbiosis was

122 demonstrated.

123

124

125

126

127

128

129

\section{Materials \& Methods}

\section{Inoculation with Rhizophagus irregularis and plant growth conditions}

$R$. irregularis was provided by Dr. Melina López-Meyer from "Centro Interdisciplinario de Investigación para el Desarrollo Integral Regional, Unidad Sinaloa”, Sinaloa state, Mexico. The inoculum was grown on Petri dishes with two compartments containing transformed carrot roots on minimum medium with $2 \%$ Gel-rite (Sigma-Aldrich) and incubated in the dark at $23 \pm 2{ }^{\circ} \mathrm{C}$ for six months according to the method reported by Bécard \& Fortin (1988).

133

Six-month-old cuttings of $S$. rebaudiana plants were cultured under greenhouse conditions.

135 Briefly, seven-cm cuttings were disinfected with $70 \%$ ethanol for $1 \mathrm{~min}$ and $2 \%$ sodium hypochlorite for $1 \mathrm{~min}$ and washed three times with sterile distilled water for $2 \mathrm{~min}$. To measure root development, the cuttings were transplanted under hydroponic conditions in glass tubes containing Fahraeus medium and cultured in a controlled environment chamber at $25^{\circ} \mathrm{C}$ with a $16 \mathrm{~h}$ light: $8 \mathrm{~h}$ dark photoperiod regimen. After ten days of culture, the rooted cuttings were transferred to plastic cones of $125 \mathrm{~mm}$ high and $32 \mathrm{~mm}$ diameter (M49, Polietilenos del Sur S.A. C.V.), one plant per cone. The substrate used was a 1:1 (v:v) mixture of vermiculite and sand. The substrate was autoclaved twice for $1 \mathrm{~h}$ at $121^{\circ} \mathrm{C}$ and $15 \mathrm{psi}$. S. rebaudiana plants were inoculated with 150 spores of $R$. irregularis $(\mathrm{M}+)$ that were homogeneously distributed in the substrate; the controls were noncolonized (M-) plants. The plants were watered twice per week with $20 \mathrm{~mL}$ of half-strength Hoagland nutrient solution (Hoagland \& Arnon, 1950) with $\mathrm{KH}_{2} \mathrm{PO}_{4}$ at the final phosphate concentrations that were evaluated: $20,200,500$, and $1000 \mu \mathrm{M}$. The $\mathrm{pH}$ of the nutrient solutions was adjusted to 6.1 .

The plants were maintained in a growth chamber at $25^{\circ} \mathrm{C}$ with a $16 \mathrm{~h}$ light: $8 \mathrm{~h}$ dark photoperiod regimen for 30 days postinoculation (dpi). The experiment was performed utilizing a complete factorial design, and six plants per phosphate concentration and colonization status with $R$. irregularis were evaluated. The controls were noncolonized plants treated with the different phosphate concentrations. Two independent experiments were performed. Similar trends were obtained in the both experiments, and the results of only one of them are shown.

157

\section{Staining and quantification of mycorrhizal colonization}

S. rebaudiana root segments were stained with 0.05\% trypan blue in lactoglycerol (Phillips \& 159 Hayman, 1970) and observed by light microscopy (BOECO Germany, BM-180) at 10-40X magnification. Total mycorrhizal colonization by $R$. irregularis was calculated according to the 
161 line-intersection method (Giovannetti \& Mosse, 1980). For each plant, 90 root segments were

162

163

164

165

166

167

168

169

170

171

172

173

174

175

176

177

178

179

180

181

182

183

184

185

186

187

188

189

190

191

192

193

194

195

196

197

198

199

200

assessed, and six plants were evaluated. The arbuscular percentage was calculated with

MycoCalc software (http://www.dijon.inra.fr/mychintec/Mycocalc-prg/download.html). To

identify the morphological type of the AM symbiosis in S. rebaudiana, mycorrhizal roots were stained with WGA-Alexa Fluor 488 to visualize the arbuscules, and the plant tissue was labeled with propidium iodide according to the methodology reported by Xie et al. (2016) using confocal laser scanning microscopy (LSM 800, Carl Zeiss).

\section{Determination of plant growth}

The plants treated with the different phosphate concentrations and colonized $(\mathrm{M}+)$ or noncolonized (M-) with $R$. irregularis were collected at 30 days postinoculation (dpi). Shoots and roots of each plant were separated, total leaves number and the fresh weight of each organ was recorded. To minimize the dependency of the analysis of expression of genes and SG quantification with the leaf position on the plant. The leaves were collected in two equivalent groups, considering their opposite arrangement of the leaves and their position along the stem. Then, leaves positioned on each side of all the nodes of the plant composed each group. The leaf area was determined by image analysis from leaves of the second node, close to the apical meristem. A stereomicroscope (Olympus SZX7, Germany) was used to obtain the micrographs. Image analysis was performed using ImageJ editing software (Version, 1.8.0.112). One half of the leaves were frozen in liquid nitrogen for molecular analysis, and the other half for SG extraction.

Root were also collected and separated longitudinally in two sections, one of them was used for determination of mycorrhizal colonization, and the other for mycorrhiza-specific phosphate transporter identification. Six plants per phosphate treatment and $R$. irregularis colonization status were evaluated.

\section{Analysis of phosphorus and magnesium concentration}

The leaves of $S$. rebaudiana plants were prepared according to Guerrero-Molina et al. (2014). The leaves were analyzed by a high-resolution scanning electron microscope (SEM) equipped with a field emission cathode and coupled to an energy-dispersive X-ray (EDX, Carl Zeiss, Oberkochen, Germany). The electron energy used was $20 \mathrm{keV}$. The mapping of $\mathrm{P}$ and $\mathrm{Mg}$ was determined by EDX to record the two-dimensional elemental composition of the leaf sample surface. For quantitative analyses, EDX spectrograms were recorded and analyzed using QUANTAX ESPRIT, Version 1.9 (BRUKER, Germany). Since the results of the concentration of each element is given as the percentage of such element with respect to all the components determined in the sample, the concentration of $\mathrm{P}$ and $\mathrm{Mg}$ in the samples was expressed as the percentage of each element in the leaves. 
201

202

203

204

205

206

207

208

209

210

211

212

213

214

215

216

217

218

219

220

221

222

223

224

225

226

227

228

229

230

231

232

233

234

235

236

237

238

239

240

\section{Determination of chlorophyll and carotenoid concentration}

The determination of chlorophyll and carotenoids concentration was made from three fresh leaves (approximately 100-150 mg) of each of the six plants of the $\mathrm{M}$ - and $\mathrm{M}+$ conditions. The leaves were collected from the upper, middle and lower part of each one of the analyzed plants and were ground in a mortar with $80 \%$ acetone. The extracts were centrifuged at $3000 \mathrm{~g}$ for 15 $\mathrm{min}$; the supernatants were separated, and the absorbance at $646.8,663.2$ and $470 \mathrm{~nm}$ was measured in a UV/Vis spectrophotometer (UV-1800, Shimadzu, Japan). The concentration of chlorophylls and carotenoids were calculated following the equations described by Khan \& Mitchell (1987).

\section{Measurement of chlorophyll fluorescence}

The chlorophyll fluorescence was measured in the second fully expanded leaf of each plant using a chlorophyll fluorometer (model OS30P, Opti-Sciences Inc., USA). The evaluation was performed at room temperature according to the instructions for the chlorophyll fluorometer. Before the evaluation, the plants were placed in the dark for $30 \mathrm{~min}$, and chlorophyll fluorescence was evaluated after applying a $1 \mathrm{~s}$ saturating pulse of actinic light $\left(3500 \mu \mathrm{mol} \mathrm{m}^{-2} \mathrm{~s}\right.$ 1). The primary fluorescence (Fo), maximal fluorescence ( $\mathrm{Fm}$ ), maximum quantum efficiency of PSII photochemistry $(\mathrm{Fv} / \mathrm{Fm})$, and potential photochemical efficiency $(\mathrm{Fv} / \mathrm{Fo})$ were calculated. $\mathrm{Fv}$ was calculated as $\mathrm{Fv}=\mathrm{Fm}-\mathrm{Fo}$, and $\mathrm{Fv} / \mathrm{Fo}$ was calculated as $\mathrm{Fv} / \mathrm{Fo}=\mathrm{Fm} / \mathrm{Fo}-1$ (Schreiber, Bilger \& Neubauer, 1994).

\section{Expression analysis by $q R T-P C R$}

The transcript accumulation levels of the genes for kaurene oxidase and (UDP)glycosyltransferases were evaluated in colonized and noncolonized plants and in plants that were treated with 200 and $1000 \mu \mathrm{M} \mathrm{KH}_{2} \mathrm{PO}_{4}$. These phosphate concentrations were selected because they were found to be the optimal and suboptimal conditions for inducing root colonization. Frozen leaves, from one of the groups described in the determination of plant growth section, were ground to a fine powder in liquid nitrogen. Total RNA was isolated from leaves using TRIzol reagent (Invitrogen, Carlsbad, CA) following the manufacturer's protocol. First-strand cDNA synthesis was performed as previously reported by Cervantes-Gámez et al. (2016).

The primers used were those designed and reported by Mandal et al. (2015) for S. rebaudiana plants. The primers correspond to the kaurene oxidase gene ( $\operatorname{SrKOF~} 5^{\prime}$ -

TCTTCACAGTCTCGGTGGTG-3', and SrKOR 5'-GGTGGTGTCGGTTTATCCTG-3'), the glucosyl transferase $U G T 74 G 1$ gene ( $S r U G T 74 G 1 F 5^{\prime}$ - GGTAGCCTGGTGAAACATGG-3', and SrUGT74GIR 5'-CTGGGAGCTTTCCCTCTTCT - 3') and the glucosyl transferase UGT76G1 gene (SrUGT76G1F 5'- GACGCGAACTGGAACTGTTG-3', and SrUGT76G1R 5'- 
241

242

243

244

245

246

247

248

249

250

251

252

253

254

255

256

257

258

259

260

261

262

263

264

265

266

267

268

269

270

271

272

273

274

275

276

277

278

279

280

AGCCGTCGGAGGTTAAGACT - 3'). qRT-PCR was performed using SYBR ${ }^{\circledR}$ Green

(QIAGEN, USA) and quantified on a Rotor-Gene Q (QIAGEN, USA) real-time PCR thermal cycler. qRT-PCR was programmed for 35 cycles, with denaturing at $95^{\circ} \mathrm{C}$ for $15 \mathrm{~s}$, annealing at $55^{\circ} \mathrm{C}$ for $30 \mathrm{~s}$, and extension at $72^{\circ} \mathrm{C}$ for $30 \mathrm{~s}$. Primer specificity was verified by regular PCR and melting curve analysis. The primers for the $S$. rebaudiana glyceraldehyde-3-phosphate dehydrogenase $(G A P D H)$ gene (SrGAPDHF 5' - TCAGGGTGGTGCCAAGAAGG-3', and SrGAPDHR 5' - TTACCTTGGCAAGGGGAGCA - 3') were used as internal controls for normalization, and the quantitative results were evaluated by the $2^{-\triangle A C T}$ method described by Livak \& Schmittgen (2001). To interpret the results, genes with fold change values $\geq 1.5$ were considered "upregulated", whereas genes with fold change values $\leq-0.7$ were considered "downregulated". Six plants per phosphate treatment and R. irregularis colonization status were evaluated.

\section{Cloning the mycorrhiza-associated phosphate transporter gene from $S$. rebaudiana}

A pair of degenerate primers (SrPTF 5'- ATGGGDTTTTTYACYGATGC-3' and SrPTR 5'GGNCCAAARTTSGCRAAGAA- $3^{\prime}$ ) were designed by aligning highly conserved regions of AM-specific phosphate transporters from M. truncatula (accession number: AY116210), A. sinicus (accession number: JQ956418), S. lycopersicum (accession number: AF022874), $S$. tuberosum (accession number: AY793559) and P. hybrida (accession number: EU532763). The PCR product was purified using the QIAquick PCR Purification Kit (QIAGEN, USA) and ligated into the pGEM ${ }^{\circledR}-\mathrm{T}$ Easy vector (Promega, USA) in accordance with the manufacturer's protocols. The presence of the correct insert (1350 bp) within the pGEM®-T Easy vector was confirmed by PCR using the universal primers T7 and SP6, and the insert was then sequenced.

Collected roots from one of the groups described in the determination of plant growth section, were ground to a fine powder in liquid nitrogen. Total RNA was obtained from the roots of six colonized $(\mathrm{M}+)$ and six noncolonized (M-) plants fertilized with $200 \mu \mathrm{M} \mathrm{K \textrm {K } _ { 2 }} \mathrm{PO}_{4}$. RNA was isolated using TRIzol reagent (Invitrogen, Carlsbad, CA) following the manufacturer's protocol. First-strand cDNA synthesis was performed as previously reported by Cervantes-Gámez et al. (2016). cDNA synthesis was confirmed by PCR using primers for the $S$. rebaudiana glyceraldehyde-3-phosphate dehydrogenase (GAPDH) gene ( $S r G A P D H F 5^{\prime}$ ATGGGDTTTTTYACYGATGC-3' and SrGAPDHR 5'- GGNCCAAARTTSGCRAAGAA- 3').

For the expression analysis of $\operatorname{Sr} P T$ in the $\mathrm{M}$ - and $\mathrm{M}+$ plants, PCRs were run in a total reaction volume of $10 \mu \mathrm{L}$, comprising $0.2 \mu \mathrm{L}$ of GoTaq ${ }^{\circledR}$ Flexi DNA Polymerase (Promega, USA), 200 $\mathrm{nM}$ of each primer, and $50 \mathrm{ng}$ of cDNA. The PCR thermocycler was programmed for 35 cycles, with denaturing at $95^{\circ} \mathrm{C}$ for $15 \mathrm{~s}$, annealing at $52^{\circ} \mathrm{C}$ for $1 \mathrm{~min}$, and extension at $72^{\circ} \mathrm{C}$ for $30 \mathrm{~s}$. The $\mathrm{SrGAPDH}$ gene was used as the reference gene. 
281

282

283

284

285

286

287

288

289

290

291

292

293

294

295

296

297

298

299

300

301

302

303

304

305

306

307

308

309

310

311

312

313

314

315

316

317

318

319

320

Homology modeling analysis of the AM-specific phosphate transporter from S. rebaudiana

BLAST analysis of the SrPT gene sequence was performed to determine homology predictions using the tools on the NCBI website (https://www.ncbi.nlm.nih.gov). To determine the conserved region of SrPT, multiple sequence alignments of AM-specific phosphate transporter proteins were performed using MULTALIN software. The homology model of SrPT transmembrane domains (TDs) was constructed according to Yadav et al. (2010), and the Mtpt4 protein structure from $M$. truncatula was used as the template for homology modeling for the $S$. rebaudiana AM-specific phosphate transporters.

\section{Steviol glycosides extraction and quantification of concentration}

The leaves of colonized $(\mathrm{M}+)$ and noncolonized (M-) plants that were treated with 200 and 1000 $\mu \mathrm{M} \mathrm{KH}_{2} \mathrm{PO}_{4}$ were used to evaluate the $\mathrm{SG}$ concentration. Leaves from one of the groups described in the determination of plant growth section, were dried in in an oven (Thermo Scientific, USA) at $65^{\circ} \mathrm{C}$ for $48 \mathrm{~h}$. The dry leaf tissue $(0.1 \mathrm{~g})$ was extracted with $1 \mathrm{~mL}$ of methanol (J.T. Backer, USA), following the methodology described by Woelwer-Rieck et al. (2010). The mixture was stirred for $3 \mathrm{~min}$, allowed to stand for $24 \mathrm{~h}$ without stirring, and then centrifuged at $10,000 \mathrm{rpm}$ at $4{ }^{\circ} \mathrm{C}$ for $10 \mathrm{~min}$. The supernatant was recovered, placed in Eppendorf tubes, and stored at $-4{ }^{\circ} \mathrm{C}$ until the analysis by HPTLC (CAMAG, Switzerland). The quantification of SGs was based on the methodology reported by Bladt and Zgainski (1996) and Morlock et al. (2014), and described recently by Villamarin-Gallegos et al. (2020). Stevioside and rebaudioside A concentration were expressed in $\mathrm{mg} \mathrm{g} \mathrm{DW}^{-1}$. Six plants per phosphate treatment and $R$. irregularis colonization status were evaluated.

\section{Statistical analysis}

The differences between the total colonization and arbuscular percentages were examined by one-way analysis of variance (ANOVA), and Tukey's post hoc test $(P<0.05)$ was performed to test the significance of differences between means. Data regarding the effect of the interaction between the $\mathrm{KH}_{2} \mathrm{PO}_{4}$ concentration and mycorrhizal colonization on plant growth, $\mathrm{P}$ and $\mathrm{Mg}$ concentration, pigment concentrations, chlorophyll fluorescence and SG concentration were subjected to factorial two-way analysis of variance (ANOVA). Tukey's post hoc test was used to analyze the differences. The paired Student's t-test was used to evaluate the significance of differences in the gene expression of kaurene oxidase and (UDP)-glycosyltransferases. All dataused for ANOVA and factorial analysis were checked for normal distributions (Shapiro-Wilk's test) before statistical analysis. All statistical analyses were performed using the statistical software IBM SPSS for Windows, Version 24.0 (Armonk, NY, IBM Corp.).

\section{Results}




\section{Phosphate concentration affects the mycorrhizal colonization of $S$. rebaudiana}

323

324

325

326

327

328

329

330

331

332

333

334

335

336

337

338

339

340

341

342

343

344

345

346

347

348

349

350

351

352

353

354

355

356

357

358

359

360

The highest percentages of colonization were obtained at 20 and $200 \mu \mathrm{M} \mathrm{KH}_{2} \mathrm{PO}_{4}(73.3$ and $67.0 \%$ colonization, respectively). In contrast, the percentage of total colonization decreased significantly at 500 and $1000 \mu \mathrm{M} \mathrm{KH}_{2} \mathrm{PO}_{4}$, with 43.3 and $18.4 \%$ colonization, respectively (Fig. 1). The percentage of arbuscules was significantly reduced at 500 and $1000 \mu \mathrm{M} \mathrm{KH}_{2} \mathrm{PO}_{4}$, with 1.48 and $0.4 \%$, respectively (Fig. 1 ).

In the roots of plants treated with $20 \mu \mathrm{M} \mathrm{KH}_{2} \mathrm{PO}_{4}$, a high number of arbuscules formed (Fig. 2A, see label *); several intraradical hyphae grew through the cortical cells (Fig. 2A, see label ih), although vesicle structures were scarce. Similar structures were observed in colonized plants $(\mathrm{M}+)$ with $200 \mu \mathrm{M} \mathrm{KH}_{2} \mathrm{PO}_{4}$; however, under these experimental conditions, the formation of arbuscules and vesicle structures was more evident (Fig. 2B, see labels * and v), indicating that $200 \mu \mathrm{M} \mathrm{KH}{ }_{2} \mathrm{PO}_{4}$ created better conditions than $20 \mu \mathrm{M}$ for the formation of arbuscules. Qualitative differences in mycorrhizal structures were observed when plants were treated with the highest $\mathrm{KH}_{2} \mathrm{PO}_{4}$ concentrations $(500$ and $1000 \mu \mathrm{M})$; the formation of arbuscules, for instance, was significantly reduced (Fig. 2C and 2D, see label *), and shortening of intraradical structures was observed (Fig. $2 \mathrm{C}$ and $\mathrm{D}$, see label ih) in comparison to the structures observed at low $\mathrm{KH}_{2} \mathrm{PO}_{4}$ concentrations (Fig. $2 \mathrm{~A}$ and $2 \mathrm{~B}$ ).

The activation of specific genes, such as the phosphate transporter specifically induced by the mycorrhizal association, is an important marker for evaluation successful colonization establishment. To our knowledge, there is no information on this transporter type in $S$. rebaudiana. For this reason, we identified a putative mycorrhiza-specific phosphate transporter in $S$. rebaudiana $(S r P T)$ by a simple PCR strategy based on degenerate oligonucleotides to clone the corresponding phosphate transporter. A 1175 bp-long genomic fragment containing an open reading frame that encodes a 391-amino acid polypeptide with a molecular mass of $43.39 \mathrm{kDa}$ was cloned (accession number: MN273502). This putative SrPT polypeptide contains 9 of the 12 transmembrane domains from the canonic phosphate transporter (Fig. S1). The bioinformatic analysis suggests that $\mathrm{SrPT}$ is $72.89 \%$ conserved in comparison to the sequences reported for MtPT4 TMDs in Medicago truncatula. Notably, SrPT transcript accumulation increased in the roots of colonized $(\mathrm{M}+)$ plants compared with that in the roots of noncolonized (M-) plants. This result suggests that this gene is positively regulated by AM symbiosis in $S$. rebaudiana, in a similar manner to the genes for other mycorrhiza-specific phosphate transporters reported in other model plants (Fig. S2).

Confocal microscopic analysis of the colonized roots and staining with the conjugate WGAAlexa Fluor ${ }^{\circledR} 488$ and propidium iodide as fluorescent markers permitted us to differentiate the hyphae and the plant cells, respectively. Intracellular hyphae and the formation of arbuscules 
361

362

363

364

365

366

367

368

369

370

371

372

373

374

375

376

377

378

379

380

381

382

383

384

385

386

387

388

389

390

391

392

393

394

395

396

397

398

399

400

from intracellular hyphae growing in the inner cortex were observed (Fig. 2E-G, see labels ih and *). With this approach, we were able to depict and classify this structure as a typical Arumtype mycorrhiza.

\section{Mycorrhizal colonization improves plant growth in $S$. rebaudiana}

In the M- plants, the leaf fresh weight was not different than that in plants treated with 20, 200 and $500 \mu \mathrm{M} \mathrm{KH}_{2} \mathrm{PO}_{4}$; the leaf fresh weight only increased significantly at $1000 \mu \mathrm{M} \mathrm{KH}_{2} \mathrm{PO}_{4}$ (Fig. 3A). In the $\mathrm{M}+$ plants, the leaf fresh weight increased by a factor of 1.74 with $200 \mu \mathrm{M}$ $\mathrm{KH}_{2} \mathrm{PO}_{4}$ in comparison to that in the M- plants (control) at the same phosphate concentration. However, no difference was found between $\mathrm{M}+$ and $\mathrm{M}$ - plants at $1000 \mu \mathrm{M} \mathrm{KH}_{2} \mathrm{PO}_{4}$. The leaves of $\mathrm{M}+$ plants with $200 \mu \mathrm{M} \mathrm{KH}_{2} \mathrm{PO}_{4}$ had a similar fresh weight to those of $\mathrm{M}+$ and M- plants treated with $1000 \mu \mathrm{M} \mathrm{KH}_{2} \mathrm{PO}_{4}$ (Fig. 3A). In plants treated with $200 \mu \mathrm{M} \mathrm{KH}_{2} \mathrm{PO}_{4}$, the fresh weight of roots was higher in the roots of $\mathrm{M}+$ plants than in the roots of M-plants. At $1000 \mu \mathrm{M}$ $\mathrm{KH}_{2} \mathrm{PO}_{4}$, the fresh weight of roots was higher in the $\mathrm{M}+$ plants than in the M- plants (Fig. 3B). Leaf number and foliar area were determined, and only at $200 \mu \mathrm{M} \mathrm{KH}_{2} \mathrm{PO}_{4}$, M- plant showed fewer leaves than $\mathrm{M}+$, as well as foliar area (Fig. S3), which is consistent with the pattern of fresh weight of leaves. Foliar area, on the other hand, was only significantly lower in $\mathrm{M}+$ plants than M- plants at $500 \mu \mathrm{M} \mathrm{KH}_{2} \mathrm{PO}_{4}$ (Fig. S3).

\section{The phosphorus and magnesium concentration increases in the leaves of colonized plants with a low phosphate concentration.}

The $\mathrm{P}$ concentration was four times higher in the leaves of $\mathrm{M}+$ plants treated with $200 \mu \mathrm{M}$ $\mathrm{KH}_{2} \mathrm{PO}_{4}$ than that in M- plants. At 500 and $1000 \mu \mathrm{M} \mathrm{KH}_{2} \mathrm{PO}_{4}$, the $\mathrm{P}$ concentration was similar in the leaves of $\mathrm{M}+$ plants and $\mathrm{M}$ - plants (Fig. 4A). In the leaves of M- plants, the $\mathrm{Mg}$ concentration increased significantly at 500 and $1000 \mu \mathrm{M} \mathrm{KH}_{2} \mathrm{PO}_{4}$, while in the leaves of $\mathrm{M}+$ plants, the $\mathrm{Mg}$ concentration increased at 20, 200 and $1000 \mu \mathrm{M} \mathrm{KH}_{2} \mathrm{PO}_{4}$, but the $\mathrm{Mg}$ concentration was lower at $500 \mu \mathrm{M} \mathrm{KH}_{2} \mathrm{PO}_{4}$ (Fig. 4B). These results suggest that $\mathrm{AM}$ symbiosis can stimulate $\mathrm{P}$ and $\mathrm{Mg}$ accumulation at low $\mathrm{KH}_{2} \mathrm{PO}_{4}$ concentrations.

\section{Chlorophyll fluorescence and the concentration of photosynthetic pigments improve in colonized plants at a low phosphate concentration}

Chlorophyll fluorescence was used as an indicator of photosynthetic performance in the $S$. rebaudiana plants. In M- plants and at all $\mathrm{KH}_{2} \mathrm{PO}_{4}$ concentrations, the $\mathrm{Fv} / \mathrm{Fm}$ ratio values were less than 0.8. In $\mathrm{M}+$ plants at 20 and $200 \mu \mathrm{M} \mathrm{KH}_{2} \mathrm{PO}_{4}$, the $\mathrm{Fv} / \mathrm{Fm}$ ratio values were greater than 0.8 , and at 500 and $1000 \mu \mathrm{M} \mathrm{KH}_{2} \mathrm{PO}_{4}$, the $\mathrm{Fv} / \mathrm{Fm}$ ratio values diminished to less than 0.8 (Fig. $5 \mathrm{~A})$. The Fv/Fo ratio is indicative of the photochemical efficiency of photosynthesis. In the Mplants at all phosphate concentrations, the values of the Fv/Fo ratio were less than 4.0. In M+ 
401 plants at 20 and $200 \mu \mathrm{M} \mathrm{KH}_{2} \mathrm{PO}_{4}$, the value of the $\mathrm{Fv} / \mathrm{Fo}$ ratio was greater than 4.0; at 500 and $4021000 \mu \mathrm{M} \mathrm{KH}_{2} \mathrm{PO}_{4}$, this ratio was less than 4.0 (Fig. 5B.). The values of Fo, Fm and Fv are 403 presented in Fig. S4.

404

The total concentration of chlorophylls and carotenoids did not change in the M- plants at any

406

407

408

409

410

411

412

413

414

415

416

417

418

419

420

421

422

423

424

425

426

427

428

429

430

431

432

433

434

435

436

437

438

439

440

phosphate concentration. However, in $\mathrm{M}+$ plants at 20 and $200 \mu \mathrm{M} \mathrm{KH}_{2} \mathrm{PO}_{4}$, the concentration of chlorophylls and carotenoids was higher as compared to the $\mathrm{M}$ - plants at the same phosphate concentrations; at 500 and $1000 \mu \mathrm{M} \mathrm{KH}_{2} \mathrm{PO}_{4}$, the concentration of the two pigments were similar in $\mathrm{M}-$ and $\mathrm{M}+$ plants (Figs. 5C and 5D).

\section{Differential expression of the genes for kaurene oxidase and glucosyltransferases in colonized plants with added phosphate}

The transcription of the kaurene oxidase $(K O)$ gene was increased 7.5 times in $\mathrm{M}+$ plants at 200 $\mu \mathrm{M} \mathrm{KH}{ }_{2} \mathrm{PO}_{4}$ compared with that in $\mathrm{M}+$ plants without added $\mathrm{KH}_{2} \mathrm{PO}_{4}$. The transcription level of the $K O$ gene did not change in $\mathrm{M}+$ plants at $1000 \mu \mathrm{M} \mathrm{KH}_{2} \mathrm{PO}_{4}$ in comparison to $\mathrm{M}$ - plants, since the relative expression $\left(2^{-\Delta \Delta C t}\right)$ was close to 1 (Fig. 6A). The $U G T 74 G 1$ gene encoding the protein involved in stevioside synthesis was upregulated in $\mathrm{M}+$ plants at $200 \mu \mathrm{M} \mathrm{KH}_{2} \mathrm{PO}_{4}$; the level of relative expression was over 1.5 (Fig. 6B). The $U G T 76 G 1$ gene encoding the protein involved in rebaudioside A synthesis was downregulated in $\mathrm{M}+$ plants at the same $\mathrm{KH}_{2} \mathrm{PO}_{4}$ concentration, and its relative expression was less than 0.7 (Fig. 6C). However, in $\mathrm{M}+$ plants at $1000 \mu \mathrm{M} \mathrm{KH}_{2} \mathrm{PO}_{4}$, the expression of the $U G T 74 G 1$ gene was downregulated, and the expression of the $U G T 76 G 1$ gene was unchanged (Fig. 6B and 6C).

\section{SGs differentially accumulate in the leaves of colonized plants with added phosphate}

In $\mathrm{M}+$ plants at $200 \mu \mathrm{M} \mathrm{KH}_{2} \mathrm{PO}_{4}$, the stevioside concentration was 2.8 times higher and the rebaudioside A concentration was 1.61 times lower than those of $\mathrm{M}$ - plants (Fig. 7A and 7B). This metabolite accumulation is consistent with the transcript levels of the corresponding glucosyl transferases (Fig 6B and C). At $1000 \mu \mathrm{M} \mathrm{KH}_{2} \mathrm{PO}_{4}$, the accumulation of the two metabolites in $\mathrm{M}+$ and $\mathrm{M}$ - plants was not affected (Fig 7A and $\mathrm{B}$ ).

\section{Discussion}

AM symbiosis enhances $\mathrm{P}$ uptake in many plants and plays an important role in agricultural and natural environments (Smith et al., 2011). Phosphate availability may change the initial signaling for the establishment, maintenance, and functioning of AM symbiosis (Schmitz \& Harrison, 2014). In this study, the low phosphate concentrations (20 and $200 \mu \mathrm{M} \mathrm{KH}_{2} \mathrm{PO}_{4}$ ) stimulated a high percentage of total mycorrhizal colonization by $R$. irregularis in $S$. rebaudiana plants, while the high $\mathrm{KH}_{2} \mathrm{PO}_{4}$ concentrations $(500$ and $1000 \mu \mathrm{M})$ decreased the colonization efficiency of $R$. 
441 irregularis in S. rebaudiana plants by approximately 30 and $70 \%$, respectively. AM symbiosis is

442 inhibited by a high concentration of $\mathrm{KH}_{2} \mathrm{PO}_{4}$ (Smith, Smith \& Jakobsen, 2004), and the

443 sensitivity and inhibition percentage depend on the plant species and AM fungus. In Medicago

444 truncatula, fertilization with $1.3 \mathrm{mM}$ phosphate reduced AM symbiosis by $80 \%$ compared to that

445 in plants fertilized with $0.13 \mathrm{mM}$ phosphate (Bonneau et al., 2013). In Petunia hybrida,

446 phosphate at $100 \mu \mathrm{M}$ induces high AM symbiosis, while phosphate at $3 \mathrm{mM}$ and higher

447 concentrations completely suppressed this symbiosis (Nouri et al., 2014). Therefore, it was

448 important in our study to define this effect of phosphate on the colonization of $R$. irregularis in

449 S. rebaudiana plants.

450

451

452

The formation of arbuscules in $S$. rebaudiana roots was inhibited to a higher extent than the total

453

454 colonization, indicating that arbuscule formation is more sensitive to high phosphate concentrations than other fungal structures, such as hyphae and vesicles. In addition, shortening

455 of intraradical structures was observed in comparison to the arbuscules of roots at low phosphate concentrations. Similarly, changes in arbuscule structures were observed in P. hybrida plants; fertilization with high phosphate concentrations significantly reduced the development of arbuscules and resulted in malformed arbuscules with fewer branches (Breuillin et al., 2010).

Previous studies in S. rebaudiana have reported colonization by $R$. irregularis, but the AM colonization morphology type has not been documented (Vafadar, Amooaghaie \& Otroshy,

461

462

463

464

465

466

467

468

469

470

471

472

473

474

475

476

477

478

479

480 2014; Mandal et al., 2015; Tavarini et al., 2018). In this study, confocal microscopic analysis with specific fluorescent dyes indicated that the AM colonization is classified as an Arum-type morphology. This AM morphotype is highly sensitive to environmental factors, including soil nutrients (Dickson et al., 2003). It is also suggested that Arum-type colonization is more efficient than other morphotypes in the acquisition and transference of phosphate from the soil to the plant, resulting in better plant growth (Van Aarle et al., 2005)

The beneficial effects of AM symbiosis on growth promotion and yield have been reported in plants from the Asteraceae family (Rapparini, Llusia \& Peñuelas, 2008; Aroca et al., 2013). In this study, AM symbiosis with $200 \mu \mathrm{M} \mathrm{KH}_{2} \mathrm{PO}_{4}$ increased colonization and arbuscule formation but also promoted the leaf and root growth in $S$. rebaudiana plants; the growth of these plants was comparable to the growth of plants fertilized at higher $\mathrm{KH}_{2} \mathrm{PO}_{4}$ concentrations $(1000 \mu \mathrm{M})$. These results suggest the activation of a high-affinity mycorrhiza-specific phosphate transporter during AM symbiosis, as reported for other plant species. In fact, we found the accumulation of transcripts of a putative phosphate transport gene in response to mycorrhizal colonization. This is the first time that a putative phosphate transporter gene has been identified in S. rebaudiana plants, and we anticipate that this gene encoding the specific phosphate transporter may contribute to growth promotion in leaves and roots. These results indicate that colonized plants are able to compensate for the deficiency in P nutrition using the mycorrhizal P uptake pathway. Similar effects have been reported in M. truncatula and P. hybrida plants at different phosphate 
481 concentrations (Balzergue et al., 2013; Nouri et al., 2014). Shoots and roots were responsive to 482 mycorrhizal colonization by increasing growth at $200 \mu \mathrm{M} \mathrm{KH}_{2} \mathrm{PO}_{4}$, whereas at $1000 \mu \mathrm{M}$

$483 \mathrm{KH}_{2} \mathrm{PO}_{4}$, roots growth was stimulated only in $\mathrm{M}+$ compared to noncolonized controls (M-). This 484 indicates that the symbiosis differentially affects shoot and root growth, and this depends on the 485 phosphate fertilization regime. In plants at $500 \mu \mathrm{M} \mathrm{KH}_{2} \mathrm{PO}_{4}$, such differences between fresh 486 weights of shoots and roots in $\mathrm{M}+$ in comparison to $\mathrm{M}$ - was not observed. This in contrast to 200

487

488

489

490

491

492

493

494

495

496

497

498

499

500

501

502

503

504

505

506

507

508

509

510

511

512

513

514

515

516

517

518

519

520 $\mu \mathrm{M}$ and $1000 \mu \mathrm{M} \mathrm{KH}_{2} \mathrm{PO}_{4}$ conditions, in which mycorrhiza-specific and direct plant phosphate uptake pathways dominate the phosphate uptake, respectively. It is possible that $500 \mu \mathrm{M}$ $\mathrm{KH}_{2} \mathrm{PO}_{4}$, the direct and the mycorrhizal-specific phosphate uptake pathways, may be interacting in such a way that no increased in growth is manifested. Although this hypothesis needs to be further studied.

Chlorophyll fluorescence is used as an indicator of light assimilation (electron transport) in the reaction centers of chlorophyll and as an indirect measurement of photosynthetic performance in plants subjected to different conditions of stress (Schreiber, Bilger \& Neubauer, 1994; Harbinson, 2013). Stress conditions may disrupt components of the photosynthetic apparatus and affect photosynthetic performance. In healthy plants, the values of the Fv/Fm ratio are between 0.79 and 0.82 ; however, under stress conditions, the photosynthetic performance is affected, and these values decrease to below 0.79. Likewise, values of the Fv/Fo ratio between 4-5 correspond to normal values for healthy plants, and values less than 4 are indicative of a loss of photosynthetic efficiency that may result from a stress condition (Baker, 2008). In the noncolonized $S$. rebaudiana plants at low $\mathrm{KH}_{2} \mathrm{PO}_{4}$ concentrations, these values were less than 0.79 and 4.0, which indicates that the plants are subjected to stress conditions. However, these values in colonized plants at the same $\mathrm{KH}_{2} \mathrm{PO}_{4}$ concentration were significantly higher than those in noncolonized plants. These results suggest that AM symbiosis may compensate for the nutritional stress induced by low $\mathrm{KH}_{2} \mathrm{PO}_{4}$ concentrations by restoring the electron transfer through PSII, regulating the functionality of the reaction center, and improving photosynthetic performance in $S$. rebaudiana plants. The results are consistent with those of other studies performed in plants under stress conditions such as high salinity, high temperatures, and water stress (Sheng et al., 2008; Zhu et al., 2011; Hu et al., 2017).

In colonized $S$. rebaudiana plants at low phosphate concentrations, the concentration of photosynthetic pigments was higher than that in noncolonized plants at the same phosphate concentration. Similarly, other authors have shown that mycorrhizal colonization stimulates the accumulation of these compounds in plants (Colla et al., 2008; Nafady \& Elgharably, 2018). These studies support the idea that photosynthesis is improved in colonized plants, which ensures carbon fixation and provides a carbon source to the fungal symbiont under low phosphate conditions (Zai et al., 2012). Additionally, increased carotenoid concentration in plants is associated with light harvesting, photoprotection, and antioxidant processes, which may contribute to improving plant growth (Walter, 2013). 
521

522

523

524

525

526

527

528

529

530

531

532

533

534

535

536

537

538

539

540

541

542

543

544

545

546

547

548

549

550

551

552

553

554

555

556

557

558

559

560

$\mathrm{Mg}$ is bound to the central atom in the porphyrin ring of chlorophyll a and b, and $25-60 \%$ of the total Mg in plants exists as chlorophyll-bound $\mathrm{Mg}$ (Chen et al., 2018). A significant increase in the $\mathrm{Mg}$ percentage was found in the leaves of $S$. rebaudiana plants colonized under the low phosphate concentration. This result is consistent with the increase in chlorophyll concentration and has been reported in other plants (Colla et al., 2008; Vafadar, Amooaghaie \& Otroshy, 2014). Thus, the increase in the concentration of chlorophylls, $\mathrm{Mg}$, and carotenoids improves plant growth and metabolite accumulation, confirming the positive effect of AM symbiosis.

Kaurene oxidase (KO) plays an important role in SG biosynthesis and represents an important branch point that specifically directs the flow of metabolites towards the biosynthesis of steviol (the central backbone of SGs). In fact, SGs are synthesized from steviol glycosylation, where the conjugation of glucose to steviol is carried out by UDP-glycosyltransferases (UGTs); for example, UGT74G1 is known to convert steviolbioside to stevioside, and UGT76G1 adds the final glucose required to produce rebaudioside A (Brandle and Telmer, 2007).

The $K O$ and $U G T 74 G 1$ gene transcription levels were upregulated in colonized plants compared to those in noncolonized plants at $200 \mu \mathrm{M} \mathrm{KH}_{2} \mathrm{PO}_{4}$, which was consistent with the observed stevioside accumulation trends. In contrast, in noncolonized plants at $200 \mu \mathrm{M} \mathrm{KH}_{2} \mathrm{PO}_{4}$, the expression of the $U G T 76 G 1$ gene and the corresponding accumulation of rebaudioside A were higher than those in colonized plants. These results indicate that plant colonization with AM stimulates stevioside accumulation, while in noncolonized plants, the accumulation of rebaudioside $\mathrm{A}$ is stimulated. In addition, the high phosphate concentration $\left(\mathrm{KH}_{2} \mathrm{PO}_{4} 1000 \mu \mathrm{M}\right)$ in colonized plants downregulated the expression of the UGT74G1 gene and did not change the expression of the $K O$ or $U G T 76 G 1$ genes at the same phosphate concentration. These results support the idea that SG synthesis is sensitive to the phosphate concentration and mycorrhizal interactions and suggest that AM symbiosis causes an increase in stevioside accumulation by modulating the expression of the $K O$ and $U G T 74 G 1$ genes, which convert steviolbioside to stevioside. The downregulation of the $U G T 76 G 1$ gene, which encodes a protein involved in transforming stevioside to rebaudioside A, may also contribute to the accumulation of stevioside. In contrast, the accumulation of rebaudioside A, which is the SG with the highest sweetening power, would be favored in noncolonized plants. This information is relevant from a biotechnological perspective. The results demonstrate the effect of the phosphate concentration on the mycorrhizal interaction between $S$. rebaudiana and $R$. irregularis as well as the effect on $\mathrm{SG}$ concentration after the modulation of the expression of key biosynthetic genes.

\section{Conclusions}

AM symbiosis between $S$. rebaudiana and $R$. irregularis is affected by phosphate concentrations; a low phosphate concentration induces a high percentage of colonization. The morphology of the

Peer) reviewing PDF | (2020:07:50625:2:0:NEW 8 Sep 2020) 
561 colonization structure was a typical Arum-type mycorrhiza, and a mycorrhiza-specific phosphate 562 transporter was identified. Colonization at low phosphate concentrations improved plant growth, 563 the chlorophyll and carotenoid concentrations, and photochemical performance. The low 564 phosphate concentration improved mycorrhizal colonization and modulated the stevioside and 565 rebaudioside A concentration by regulating the transcription of genes that encode kaurene 566 oxidase and glucosyltransferases, which are involved in the synthesis of these compounds in $S$. 567 rebaudiana. This knowledge is important for generating biotechnological strategies that involve 568 manipulating the concentration of stevioside or rebaudioside A by controlling the colonization 569 status and the phosphate concentration of S. rebaudiana plants.

570

571

572

573 The authors thank, in particular, Consejo Nacional de Ciencia y Tecnología (Curriculum Vitae

574 Único: 480787) and Secretaría de Investigación y posgrado-Instituto Politécnico Nacional (Beca

575 de Estímulo Institucional de Formación de Investigadores) for their assistance. This work was

576 conducted with the support of Secretaría de Investigación y posgrado-Instituto Politécnico

577 Nacional (projects: 20180427, 20181785 and 20195064) and Dirección General de Asuntos del

578 Personal Académico IN209118 and CV200519. We owe special thanks to Silvia Evangelista

579 Lozano from CeProBi-IPN for providing Stevia rebaudiana plants. The authors thank Daniel

580 Tapía Maruri for the excellent technical assistance in producing confocal laser scanning

581 microscope images.

582

583

584

585

586

587

588

589

590

591

592

593

594

595

596

597

598

599

600

601

602

\section{References}

Aroca R, Ruiz-Lozano JM, Zamarreño-Ángel M, Paz JA, García-Mina JM, Pozo MJ, LópezRáez JA. 2013. Arbuscular mycorrhizal symbiosis influences strigolactone production under salinity and alleviates salt stress in lettuce plants. Journal of Plant Physiology 170: 47-55. DOI: 10.1016/j.jplph.2012.08.020.

Baker NR. 2008. Chlorophyll fluorescence: A probe of photosynthesis in vivo. Annual Review of Plant Biology 59: 89-113. DOI: 10.1146/annurev.arplant.59.032607.092759.

Balzergue C, Chabaud M, Barker DG, Bécard G, Rochange SF. 2013. High phosphate reduces host ability to develop arbuscular mycorrhizal symbiosis without affecting root calcium spiking responses to the fungus. Frontiers in Plant Science 4: 1-15. DOI: 10.3389/fpls.2013.00426.

Bécard G, Fortin JA. 1988. Early events of vesicular-arbuscular mycorrhiza formation on Ri TDNA transformed roots. New Phytologist 108: 211-218. DOI: 10.1111/j.14698137.1988.tb03698.x.

Bladt S, Zgainski E. 1996. Plant Drug Analysis: A Thin Layer Chromatography Atlas. Springer Science \& Business Media. Springer-Verlag; Brooklyn, NY, USA. ISBN 3-540-58676-8 
603

604

605

606

607

608

609

610

611

612

613

614

615

616

617

618

619

620

621

622

623

624

625

626

627

628

629

630

631

632

633

634

635

636

637

638

639

640

641

642

643

644

645

Bonneau L, Huguet S, Wipf D, Pauly N, Truong HN. 2013. Combined phosphate and nitrogen limitation generates a nutrient stress transcriptome favorable for arbuscular mycorrhizal symbiosis in Medicago truncatula. New Phytologist 199: 188-202. DOI: $10.1111 /$ nph.12234.

Brandle JE, Starratt AN, Gijzen M. 1998. Stevia rebaudiana: Its agricultural, biological, and chemical properties. Canadian Journal of Plant Science 78:527-536. DOI: 10.4141/P97114.

Brandle JE, Telmer PG. 2007. Steviol glycoside biosynthesis. Phytochemistry 68:1855-1863. DOI: 10.1016/j.phytochem.2007.02.010.

Breuillin F, Schramm J, Hajirezaei M, Ahkami A, Favre P, Druege U, Hause B, Bucher M, Kretzschmar T, Bossolini E, Kuhlemeier C, Martinoia E, Franken P, Scholz U, Reinhardt D. 2010. Phosphate systemically inhibits development of arbuscular mycorrhiza in Petunia hybrida and represses genes involved in mycorrhizal functioning. Plant Journal 64: 10021017. DOI: $10.1111 /$ j.1365-313X.2010.04385.x.

Cervantes-Gámez RG, Bueno-Ibarra MA, Cruz-Mendívil A, Calderón-Vázquez CL, RamírezDouriet CM, Maldonado-Mendoza IE, Villalobos-López MÁ, Valdez-Ortíz Á, LópezMeyer M. 2016. Arbuscular mycorrhizal symbiosis-induced expression changes in Solanum lycopersicum leaves revealed by RNA-seq analysis. Plant Molecular Biology Reporter 34: 89-102. DOI: 10.1007/s11105-015-0903-9.

Chen ZC, Peng WT, Li J, Liao H. 2018. Functional dissection and transport mechanism of magnesium in plants. Seminars in Cell and Developmental Biology 74: 142-152. DOI: 10.1016/j.semcdb.2017.08.005.

Colla G, Rouphael Y, Cardarelli M, Tullio M, Rivera CM, Rea E. 2008. Alleviation of salt stress by arbuscular mycorrhizal in zucchini plants grown at low and high phosphorus concentration. Biology and Fertility of Soils 44: 501-509. DOI: 10.1007/s00374-007-02328.

Dickson S, Schweiger P, Smith S, Söderström B, Smith FA. 2003. Paired arbuscules in the Arum -type arbuscular mycorrhizal symbiosis with Linum usitatissimum. Canadian Journal of Botany 81: 457-463. DOI: 10.1139/b03-037.

Giovannetti M, Mosse B. 1980. An evaluation of techniques for measuring vesicular arbuscular mycorrhizal infection in roots. New Phytologist:489-500. DOI: 10.1111/j.14698137.1980.tb04556.x.

Guerrero-Molina MF, Lovaisa NC, Salazar SM, Díaz-Ricci JC, Pedraza RO. 2014. Elemental composition of strawberry plants inoculated with the plant growth-promoting bacterium

Peer) reviewing PDF | (2020:07:50625:2:0:NEW 8 Sep 2020) 
646

647

648

649

650

651

652

653

654

655

656

657

658

659

660

661

662

663

664

665

666

667

668

669

670

671

672

673

674

675

676

677

678

679

680

681

682

683

684

685

686

687

688

689

690

691

Azospirillum brasilense REC3, assessed with scanning electron microscopy and energy dispersive X-ray analysis. Plant Biology 16:726-731. DOI: 10.1111/plb.12114.

Harbinson J. 2013. Improving the accuracy of chlorophyll fluorescence measurements. Plant, Cell and Environment 36: 1751-1754. DOI: 10.1111/pce.12111.

Harrison MJ, Dewbre GR, Liu J. 2002. A phosphate transporter from Medicago truncatula involved in the acquisition of phosphate released by arbuscular mycorrhizal fungi. The Plant Cell 14:2413-2429. DOI: 10.1105/tpc.004861

Hoagland DR, Arnon DI. 1950. The water-culture method for growing plants without soil. California Agrcultural Experiment Station 347: 1-32.

$\mathrm{Hu}$ W, Zhang H, Chen H, Tang M. 2017. Arbuscular mycorrhizas influence Lycium barbarum tolerance of water stress in a hot environment. Mycorrhiza 27: 451-463. DOI: 10.1007/s00572-017-0765-0.

Karandashov V, Bucher M. 2005. Symbiotic phosphate transport in arbuscular mycorrhizas. Trends in Plant Science 10:22-29. DOI: 10.1016/j.tplants.2004.12.003.

Khan MU, Mitchell K. 1987. Chlorophylls and carotenoids: pigments of photosynthetic biomembranes. Methods in Enzymology. 48: 350-382.

Kim MJ, Zheng J, Liao MH, Jang IC. 2019. Overexpression of SrUGT76G1 in Stevia alters major steviol glycosides composition towards improved quality. Plant Biotechnology Journal 17: 1037-1047. DOI: 10.1111/pbi.13035.

Lemus-Mondaca R, Vega-Gálvez A, Zura-Bravo L, Kong AH. 2012. Stevia rebaudiana Bertoni, source of a high-potency natural sweetener: A comprehensive review on the biochemical, nutritional and functional aspects. Food Chemistry 132: 1121-1132. DOI:

10.1016/j.foodchem.2011.11.140.

Livak KJ, Schmittgen TD. 2001. Analysis of relative gene expression data using real-time quantitative PCR and the $2^{-\Delta \Delta C T}$ method. Methods 25: 402-408. DOI:

10.1006/meth.2001.1262.

Mandal S, Evelin H, Giri B, Singh VP, Kapoor R. 2013. Arbuscular mycorrhiza enhances the production of stevioside and rebaudioside-A in Stevia rebaudiana via nutritional and nonnutritional mechanisms. Applied Soil Ecology 72:187-194. DOI:

10.1016/j.apsoil.2013.07.003.

Mandal S, Upadhyay S, Singh VP, Kapoor R. 2015. Enhanced production of steviol glycosides in mycorrhizal plants: A concerted effect of arbuscular mycorrhizal symbiosis on transcription of biosynthetic genes. Plant Physiology and Biochemistry 89:100-106. DOI: 10.1016/j.plaphy.2015.02.010.

Peer) reviewing PDF | (2020:07:50625:2:0:NEW 8 Sep 2020) 
692 Morlock G, Meyer S, Zimmermann B, Roussel J. 2014. High-performance thin layer 693 chromatography analysis of steviol glycosides in stevia formulations and sugar-free food products, and benchmarking with (ultra) high performance liquid chromatography. Journal of Chromatography A 1350, 102-111. DOI: org/10.1016/j.chroma.2014.05.016.

Nafady NA, Elgharably A. 2018. Mycorrhizal symbiosis and phosphorus fertilization effects on Zea mays growth and heavy metals uptake. International Journal of Phytoremediation 20:869-875. DOI: $10.1080 / 15226514.2018 .1438358$.

Nagy R, Karandashov V, Chague V, Kalinkevich K, Tamasloukht M, Xu G, Jakobsen I, Levy AA, Amrhein N, Bucher M. 2005. The characterization of novel mycorrhiza-specific phosphate transporters from Lycopersicon esculentum and Solanum tuberosum uncovers functional redundancy in symbiotic phosphate transport in solanaceous species. Plant Journal 42:236-250. DOI: 10.1111/j.1365-313X.2005.02364.x.

Nouri E, Breuillin-Sessoms F, Feller U, Reinhardt D. 2014. Phosphorus and nitrogen regulate arbuscular mycorrhizal symbiosis in petunia hybrida. PLoS ONE 9. DOI: 10.1371/journal.pone.0090841.

Phillips JM, Hayman DS. 1970. Improved procedures for clearing roots and staining parasitic and vesicular-arbuscular mycorrhizal fungi for rapid assessment of infection. Transactions of the British Mycological Society 55:158-IN18. DOI: 10.1016/S0007-1536(70)80110-3.

Rapparini F, Llusià J, Peñuelas J. 2008. Effect of arbuscular mycorrhizal (AM) colonization on terpene emission and content of Artemisia annua L. Plant Biology 10: 108-122. DOI: $10.1055 / \mathrm{s}-2007-964963$.

Schmitz AM, Harrison MJ. 2014. Signaling events during initiation of arbuscular mycorrhizal symbiosis. Journal of Integrative Plant Biology 56:250-261. DOI: 10.1111/jipb.12155.

Schoefs B, Uddling J, Spetea C, Adolfsson L, Keresztes Á, Andersson MX, Solymosi K. 2015. Mycorrhiza symbiosis increases the surface for sunlight capture in Medicago truncatula for better photosynthetic production. Plos One 10:e0115314. DOI: 10.1371/journal.pone.0115314.

Schreiber U, Bilger, W, Neubauer, C. 1994. Chlorophyll fluorescence as an non-intrusive indicator for rapid assesment of in vivo photosynthesis. In: Schulze ED, Caldwell MM. 1995. Ecophysiology of photosynthesis. Springer Verlag, 47-70. https://doi.org/10.1016/1011-1344(95)90135-3.

Sheng M, Tang M, Chen H, Yang B, Zhang F, Huang Y. 2008. Influence of arbuscular mycorrhizae on photosynthesis and water status of maize plants under salt stress. Mycorrhiza 18: 287-296. https://doi.org/10.1007/s00572-008-0180-7.

Smith SE, Jakobsen I, Gronlund M, Smith FA. 2011. Roles of arbuscular mycorrhizas in plant phosphorus nutrition: interactions between pathways of phosphorus uptake in arbuscular 
738

739

740

741

742

743

744

745

746

747

748

749

750

751

752

753

754

755

756

757

758

759

760

761

762

763

764

765

766

767

768

769

770

771

772

773

774

775

776

777

778

779

780 mycorrhizal roots have important implications for understanding and manipulating plant phosphorus acquisition. Plant Physiology 156:1050-1057. DOI: 10.1104/pp.111.174581.

Smith SE, Read DJ. 2008. Mycorrhizal symbiosis 3rd Ed. New York, NY: Academic Press.

Smith SE, Smith FA, Jakobsen I. 2004. Functional diversity in arbuscular mycorrhizal (AM) symbioses: The contribution of the mycorrhizal $\mathrm{P}$ uptake pathway is not correlated with mycorrhizal responses in growth or total P uptake. New Phytologist 162:511-524. DOI: 10.1111/j.1469-8137.2004.01039.x.

Spatafora JW, Chang Y, Benny GL, Lazarus K, Smith ME, Berbee ML, Bonito G, Corradi N, Grigoriev I, Gryganskyi A, James TY, O’Donnell K, Roberson RW, Taylor TN, Uehling J, Vilgalys R, White MM, Stajich JE. 2016. A phylum-level phylogenetic classification of zygomycete fungi based on genome-scale data. Mycologia 25:289-313. DOI: 110.1016/j.bbi.2017.04.008.

Tavarini S, Passera B, Martini A, Avio L, Sbrana C, Giovannetti M, Angelini LG. 2018. Plant growth, steviol glycosides and nutrient uptake as affected by arbuscular mycorrhizal fungi and phosphorous fertilization in Stevia rebaudiana Bert. Industrial Crops and Products 111: 899-907. DOI: 10.1016/j.indcrop.2017.10.055.

Totté N, Charon L, Rohmer M, Compernolle F, Baboeuf I, Geuns JMC. 2000. Biosynthesis of the diterpenoid steviol, an ent-kaurene derivative from Stevia rebaudiana Bertoni, via the methylerythritol phosphate pathway. Tetrahedron Letters 41:6407-6410. DOI: 10.1016/S0040-4039(00)01094-7.

Vafadar F, Amooaghaie R, Otroshy M. 2014. Effects of plant-growth-promoting rhizobacteria and arbuscular mycorrhizal fungus on plant growth, stevioside, NPK, and chlorophyll content of Stevia rebaudiana. Journal of Plant Interactions 9:128-136. DOI: 10.1080/17429145.2013.779035.

Van Aarle IM, Cavagnaro TR, Smith SE, Smith FA, Dickson S. 2005. Metabolic activity of Glomus intraradices in Arum- and Paris-type arbuscular mycorrhizal colonization. New Phytologist 166:611-618. DOI: 10.1111/j.1469-8137.2005.01340.x.

Villamarin-Gallegos D, Oviedo-Pereira DG, Evangelista-Lozano S, Sepúlveda-Jiménez G, Molina-Torres J, Rodríguez-Monroy. 2020. Trichoderma asperellum, an inoculant for the micropropagation of Stevia rebaudiana Bertoni in a temporary immersion bioreactor. Revista Mexicana de Ingeniería Química 19 (3): 1153-1161. DOI: 10.24275/rmiq/Bio947.

Walter M. 2013. Role of carotenoid metabolism in the arbuscular mycorrhizal symbiosis. In: Bruijn FJ. 2013. Molecular microbial ecology of the rhizosphere. Wiley Blackwell, 513524. https://doi.org/10.1002/9781118297674. 
781

782

783

784

785

786

787

788

789

790

791

792

793

794

795

796

797

798

799

800

801

802

803

804

805

806

807

808

809

810

811

812

813

814

815

816

817

818

819

820

821

822

823

824

825

826
Woelwer-Rieck U, Lankes C, Wawrzun A, Wüst M. 2010. Improved HPLC method for the evaluation of the major steviol glycosides in leaves of Stevia rebaudiana. European Food Research and Technology 231:581-588. DOI: 10.1007/s00217-010-1309-4.

Xie X, Lin H, Peng X, Xu C, Sun Z, Jiang K, Huang A, Wu X, Tang N, Salvioli A, Bonfante P, Zhao B. 2016. Arbuscular mycorrhizal symbiosis requires a phosphate transceptor in the Gigaspora margarita fungal symbiont. Molecular Plant 9:1583-1608. DOI: 10.1016/j.molp.2016.08.011.

Yadav V, Kumar M, Deep AK, Kumar H, Sharma R, Tripathi T, Tuteja N, Saxena AK, Johri AK. 2010. A phosphate transporter from the root endophytic fungus Piriformospora indica plays a role in phosphate transport to the host plant. Journal of Biological Chemistry 285:26532-26544. DOI: 10.1074/jbc.M110.111021.

Zai XM, Zhu SN, Qin P, Wang XY, Che L, Luo FX. 2012. Effect of Glomus mosseae on chlorophyll content, chlorophyll fluorescence parameters, and chloroplast ultrastructure of beach plum (Prunus maritima) under NaCl stress. Photosynthetica 50: 323-328. DOI: 10.1007/s11099-012-0035-5.

Zhu XC, Song F Bin, Liu SQ, Liu TD. 2011. Effects of arbuscular mycorrhizal fungus on photosynthesis and water status of maize under high temperature stress. Plant and Soil 346:189-199. DOI: 10.1007/s11104-011-0809-8. 
827

828

829

830

831

832

833

834

835

836

837

838

839

840

841

842

843

844

845

846

847

848

849

850

851

852

853

854

855

856

857

858

859

860

861

862

863

864

865

866

867

868

Figure 1. Quantification of mycorrhizal colonization in $\boldsymbol{S}$. rebaudiana roots. Percentages of total mycorrhizal colonization (dotted bars) and arbuscule colonization (diagonally hatched bars) by $R$. irregularis in $S$. rebaudiana plants fertilized with Hoagland nutrient solution at different $\mathrm{KH}_{2} \mathrm{PO}_{4}$ concentrations. Bars represent the mean \pm standard deviation (SD) of six replicates. Different letters indicate significant differences according to Tukey's test $(P<0.05)$. Capital letters were used for total colonization, and lowercase letters were used for arbuscular colonization.

Figure 2. Light and confocal microscopic analysis of $\boldsymbol{R}$. irregularis colonization structures in $S$. rebaudiana roots. Mycorrhiza-colonized roots of $S$. rebaudiana plants fertilized with 20 (A), 200 (B), 500 (C) and $1000 \mu \mathrm{M} \mathrm{KH}_{2} \mathrm{PO}_{4}$ (D) after trypan blue staining depicting the arbuscules, vesicles and intraradical hyphae. Mycorrhiza-colonized roots with $200 \mu \mathrm{M} \mathrm{KH}_{2} \mathrm{PO}_{4}$ were also treated with propidium iodide to label the cell wall (E) and with WGA-Alexa Fluor 488 conjugate to stain the fine details of the intraradical hyphae and arbuscules ( $F$ and $G)$. The merged image showing both red and green fluorescence is presented in panel G. Vesicles: V; intraradical hyphae: ih; arbuscules: *.

Figure 3. Effect of AM symbiosis and $\mathrm{KH}_{2} \mathrm{PO}_{4}$ concentrations on the fresh weight of $\boldsymbol{S}$. rebaudiana roots and leaves. Fresh weight of leaves (A) and roots (B) of mycorrhiza-colonized $(\mathrm{M}+)$ and noncolonized (M-) S. rebaudiana plants fertilized with Hoagland solution with different $\mathrm{KH}_{2} \mathrm{PO}_{4}$ concentrations. Bars represent the mean \pm standard deviation (SD) of six replicates. Different letters indicate significant differences according to Tukey's test $(P<0.05)$.

\section{Figure 4. Quantification of $P$ and $M g$ under $A M$ symbiosis and different $\mathrm{KH}_{2} \mathrm{PO}_{4}$} concentrations. Phosphorus (A) and magnesium (B) concentration in the leaves of mycorrhizacolonized (M+) and noncolonized (M-) S. rebaudiana plants fertilized with Hoagland solution at different $\mathrm{KH}_{2} \mathrm{PO}_{4}$ concentrations. Bars represent the mean \pm standard deviation (SD) of six replicates. Different letters indicate significant differences according to Tukey's test $(P<0.05)$.

\section{Figure 5. Effects of AM symbiosis and $\mathrm{KH}_{2} \mathrm{PO}_{4}$ concentrations on photosynthetic} performance in $\boldsymbol{S}$. rebaudiana. Maximal photochemical efficiency (Fv/Fm) (a), potential photochemical efficiency (Fv/Fo) (b), and total chlorophylls (c), and carotenoids concentration (d) in leaves of mycorrhiza-colonized (M+) and noncolonized (M-) S. rebaudiana plants fertilized with Hoagland solution at different $\mathrm{KH}_{2} \mathrm{PO}_{4}$ concentrations. Fv/Fm and Fv/Fo ratios were obtained from chlorophyll fluorescence measurements. Bars represent the mean \pm standard deviation (SD) of six replicates. Different letters indicate significant differences according to Tukey's test $(P<0.05)$.

Peer) reviewing PDF | (2020:07:50625:2:0:NEW 8 Sep 2020) 
869 Figure 6. Differential transcript accumulation of three key genes from the SG biosynthetic 870 pathway under AM symbiosis and different $\mathbf{K H}_{2} \mathbf{P O}_{4}$ concentrations. $K O(\mathrm{~A}), U G T 74 G 1$ (B)

871 and $U G T 76 G 1$ (C) relative expression levels in $S$. rebaudiana plants that were mycorrhiza-

872 colonized and fertilized with Hoagland solution at 200 and $1000 \mu \mathrm{M} \mathrm{KH}_{2} \mathrm{PO}_{4}$. For each

873 condition, the transcript levels of the KO,UGT74G1 and UGT76G1 genes were first normalized

874 against $\operatorname{SrGAPDH}$ and then normalized against the gene expression of $S$. rebaudiana without

875 inoculation. The analysis of the relative gene expression data used the $2^{-\triangle \triangle C T}$ method. Bars

876 represent the mean \pm standard deviation (SD) of three biological and three technical replicates.

877 Different letters indicate significant differences according to Student's $t$ test $(P<0.05)$.

878

879

Figure 7. Quantification of SG concentration under AM symbiosis and different $\mathrm{KH}_{2} \mathrm{PO}_{4}$

880 concentrations. Stevioside (A) and rebaudioside A (B) concentration in mycorrhiza-colonized

881

882

883

884

885

886

887

888

889

890

891

892

893

894

895

896

897

898

899

900

901

902

903

904

905

906

907

908 $(\mathrm{M}+)$ and noncolonized (M-) S. rebaudiana plants fertilized with Hoagland solution at 200 and $1000 \mu \mathrm{M} \mathrm{KH}_{2} \mathrm{PO}_{4}$. Bars represent the mean \pm standard deviation (SD) of six replicates. Different letters indicate significant differences according to Tukey's test $(P<0.05)$.

Figure S1. Protein sequence structure of the mycorrhiza-specific phosphate transporter (SrPT) from $S$. rebaudiana. The SrPT protein contains 391 amino acids and 9 TM domains. The alignment that was used to deduce the amino acid sequence and topology of the 12 SrPT TM domains (TM1-TM12) was predicted using AM-specific phosphate transporters from $M$. truncatula (MtPT4), A. sinicus (AsPT4), S. tuberosum (StPT4), L. esculentum (LePT4), and P. hybrida (PhPT4). The deduced amino acid sequence was aligned through MULTIALIN, and SrPT was predicted according to Yadav et al. (2010).

\section{Figure S2. Expression analysis of the $S r P T$ gene in roots of individual $M-$ and $M+S$.} rebaudiana plants. Lanes 1-6, replicates of noncolonized (M-) and $R$. irregularis-colonized plants $(\mathrm{M}+)$. $S r G A D P H$ was used as a reference gene.

Figure S3. Effects of AM symbiosis and $\mathrm{KH}_{2} \mathrm{PO}_{4}$ concentration on aerial part development in S. rebaudiana. Leaves number (A) and foliar area in leaves of mycorrhiza-colonized (M+) and noncolonized (M-) S. rebaudiana plants fertilized with Hoagland solution using different $\mathrm{KH}_{2} \mathrm{PO}_{4}$ concentrations Bars represent the mean \pm standard deviation (SD) of six replicates. Different letters indicate significant differences according to Tukey's test $(P<0.05)$.

Figure S4. Effects of AM symbiosis and $\mathrm{KH}_{2} \mathrm{PO}_{4}$ concentration on chlorophyll fluorescence in $S$. rebaudiana. Primary fluorescence (Fo) (A), maximal fluorescence (Fm) (B), and variable fluorescence (Fv) (C) in leaves of mycorrhiza-colonized (M+) and noncolonized (M-) $S$. rebaudiana plants fertilized with Hoagland solution using different $\mathrm{KH}_{2} \mathrm{PO}_{4}$ concentrations. Bars represent the mean \pm standard deviation (SD) of six replicates. Different letters indicate significant differences according to Tukey's test $(P<0.05)$. 
Figure 1

Figure 1. Quantification of mycorrhizal colonization in S. rebaudiana roots.

Percentages of total mycorrhizal colonization (dotted bars) and arbuscule colonization (diagonally hatched bars) by $R$. irregularis in S. rebaudiana plants fertilized with Hoagland nutrient solution at different $\mathrm{KH}_{2} \mathrm{PO}_{4}$ concentrations. Bars represent the mean \pm standard deviation (SD) of six replicates. Different letters indicate significant differences according to Tukey's test $(P<0.05)$. Capital letters were used for total colonization, and lowercase letters were used for arbuscular colonization.

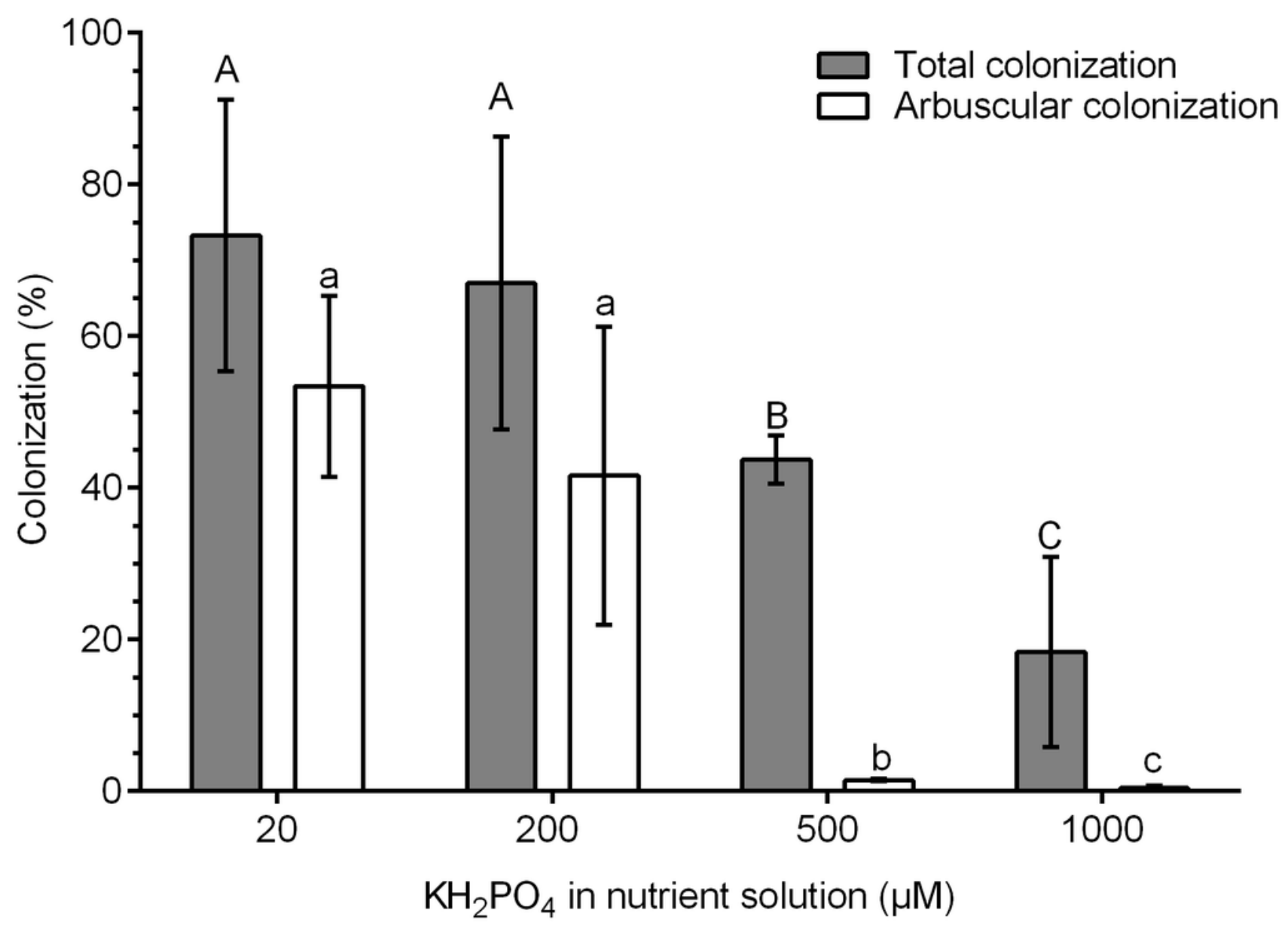




\section{Figure 2}

Figure 2. Light and confocal microscopic analysis of $R$. irregularis colonization structures in $\mathrm{S}$. rebaudiana roots.

Mycorrhiza-colonized roots of S. rebaudiana plants fertilized with 20 (A), 200 (B), 500 (C) and $1000 \mu \mathrm{M} \mathrm{KH}_{2} \mathrm{PO}_{4}(\mathrm{D})$ after trypan blue staining depicting the arbuscules, vesicles and intraradical hyphae. Mycorrhiza-colonized roots with $200 \mu \mathrm{M} \mathrm{KH}_{2} \mathrm{PO}_{4}$ were also treated with propidium iodide to label the cell wall (E) and with WGA-Alexa Fluor 488 conjugate to stain the fine details of the intraradical hyphae and arbuscules ( $F$ and $G$ ). The merged image showing both red and green fluorescence is presented in panel G. Vesicles: V; intraradical hyphae: ih; arbuscules: *. 

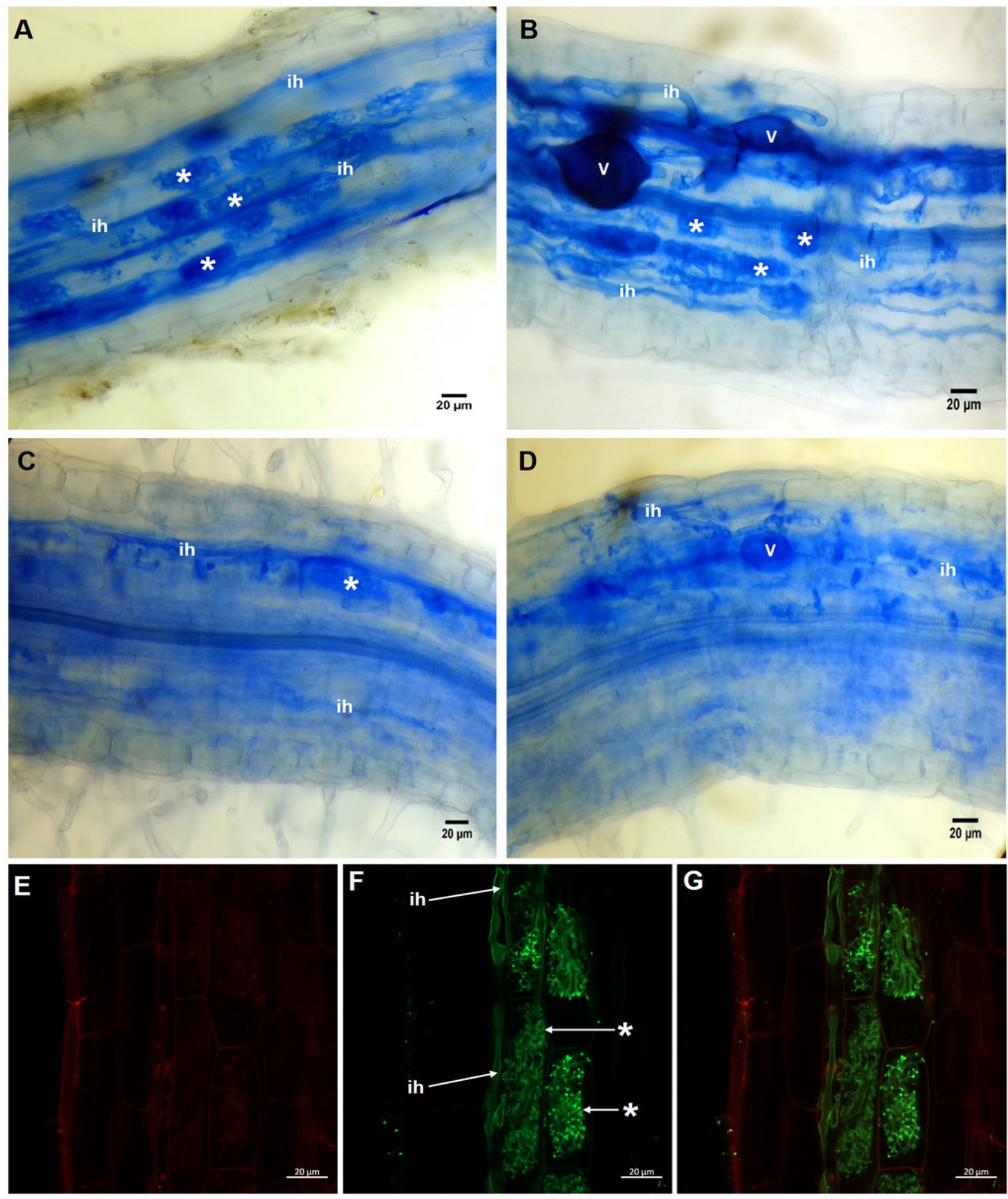


\section{Figure 3}

Figure 3. Effect of AM symbiosis and $\mathrm{KH}_{2} \mathrm{PO}_{4}$ concentrations on the fresh weight of $S$. rebaudiana roots and leaves.

Fresh weight of leaves $(A)$ and roots $(B)$ of mycorrhiza-colonized $(M+)$ and noncolonized $(M-)$ S. rebaudiana plants fertilized with Hoagland solution with different $\mathrm{KH}_{2} \mathrm{PO}_{4}$ concentrations. Bars represent the mean \pm standard deviation (SD) of six replicates. Different letters indicate significant differences according to Tukey's test $(P<0.05)$. 

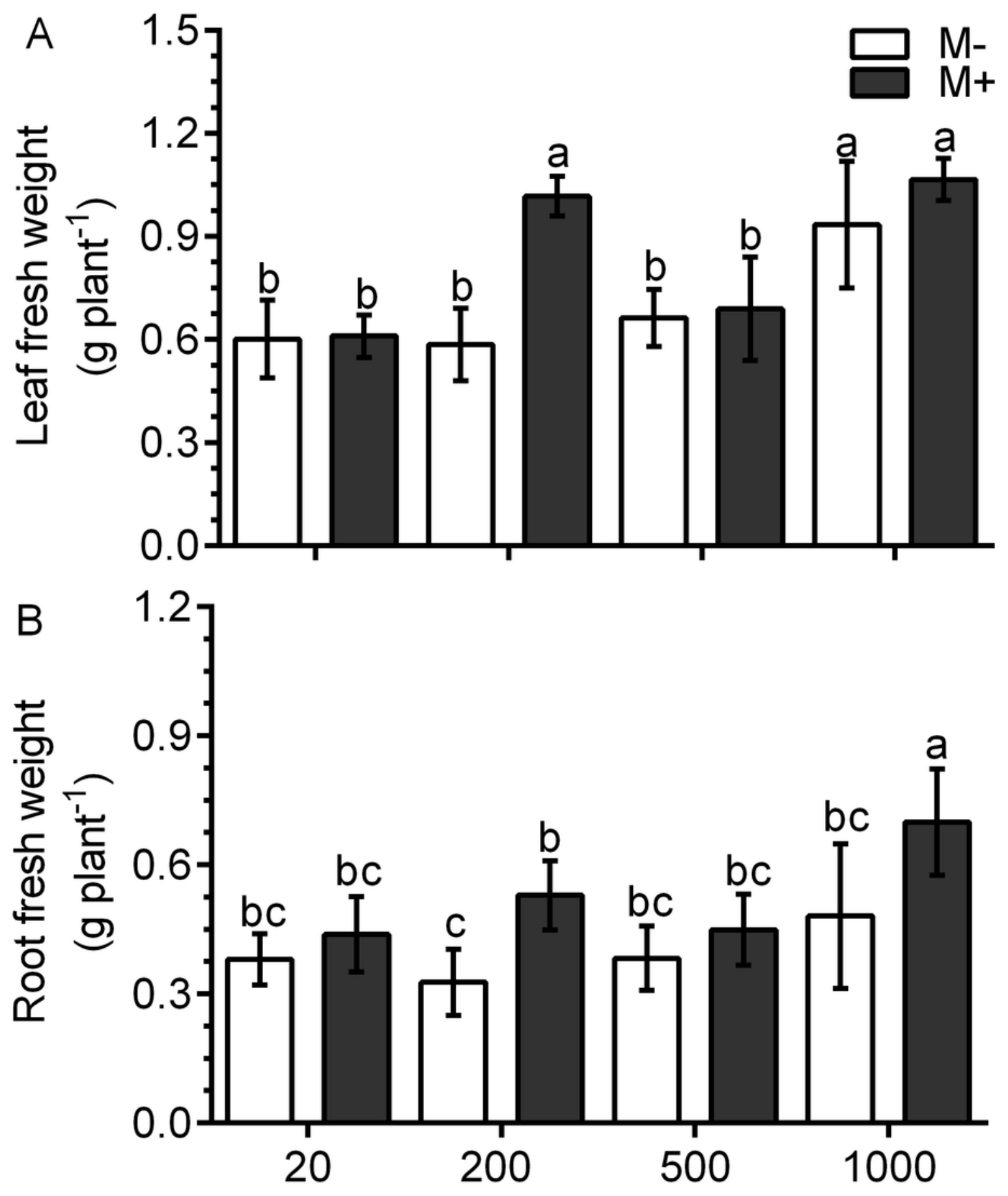

$\mathrm{KH}_{2} \mathrm{PO}_{4}$ in nutrient solution $(\mu \mathrm{M})$ 


\section{Figure 4}

Figure 4. Quantification of $\mathrm{P}$ and $\mathrm{Mg}$ under $\mathrm{AM}$ symbiosis and different $\mathrm{KH}_{2} \mathrm{PO}_{4}$ concentrations.

Phosphorus (A) and magnesium (B) concentration in the leaves of mycorrhiza-colonized $(\mathrm{M}+$ ) and noncolonized (M-) S. rebaudiana plants fertilized with Hoagland solution at different $\mathrm{KH}_{2} \mathrm{PO}_{4}$ concentrations. Bars represent the mean \pm standard deviation (SD) of six replicates. Different letters indicate significant differences according to Tukey's test $(P<0.05)$. 


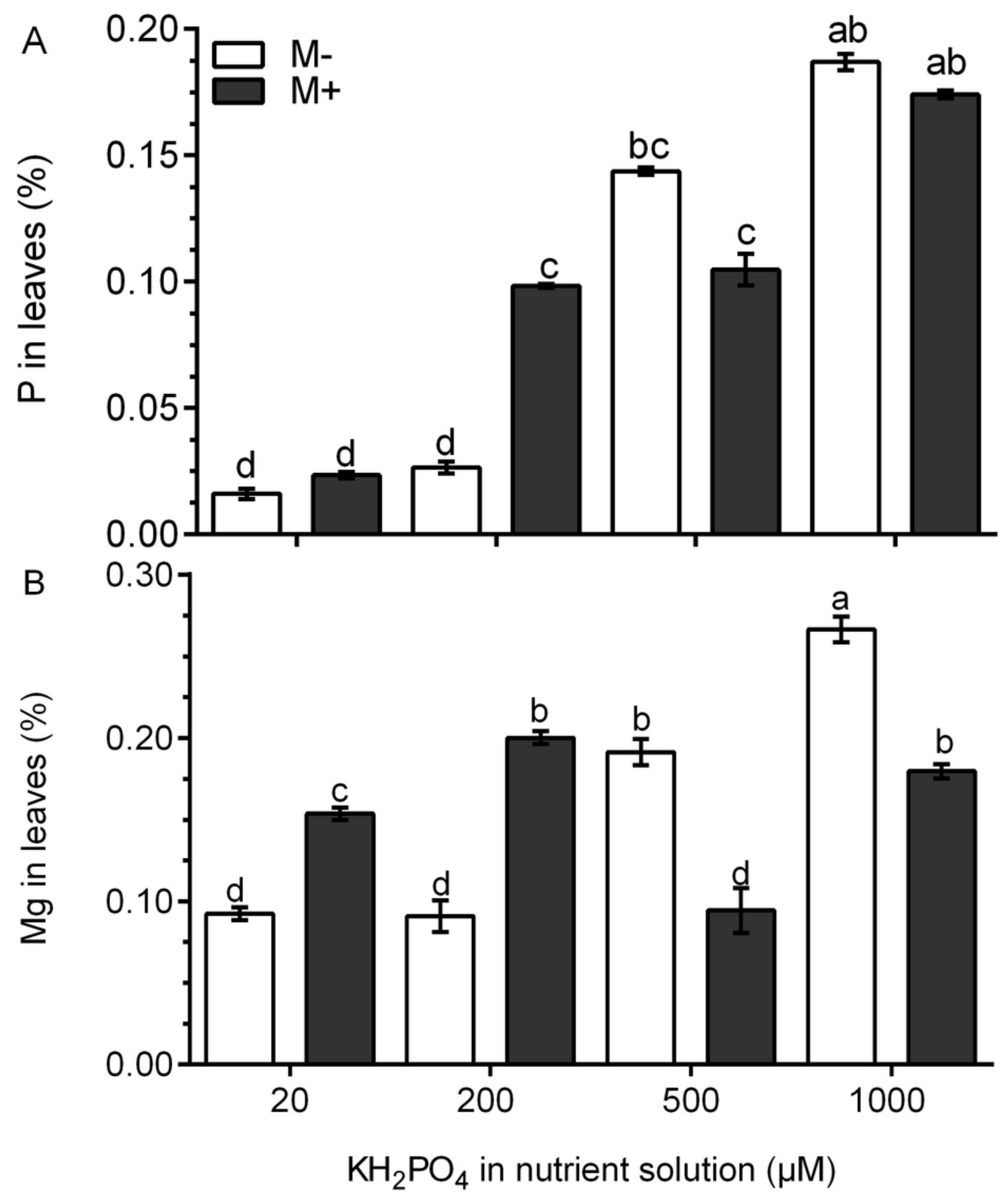




\section{Figure 5}

Figure 5. Effects of $\mathrm{AM}$ symbiosis and $\mathrm{KH}_{2} \mathrm{PO}_{4}$ concentrations on photosynthetic performance in S. rebaudiana.

Maximal photochemical efficiency (Fv/Fm) (a) , potential photochemical efficiency (Fv/Fo) (b), and total chlorophyll (c), and carotenoid contents (d) in leaves of mycorrhiza-colonized $(M+)$ and noncolonized (M-) S. rebaudiana plants fertilized with Hoagland solution at different $\mathrm{KH}_{2} \mathrm{PO}_{4}$ concentrations. $\mathrm{Fv} / \mathrm{Fm}$ and $\mathrm{Fv} / \mathrm{Fo}$ ratios were obtained from chlorophyll fluorescence measurements. Bars represent the mean \pm standard deviation (SD) of six replicates. Different letters indicate significant differences according to Tukey's test $(P<0.05)$.
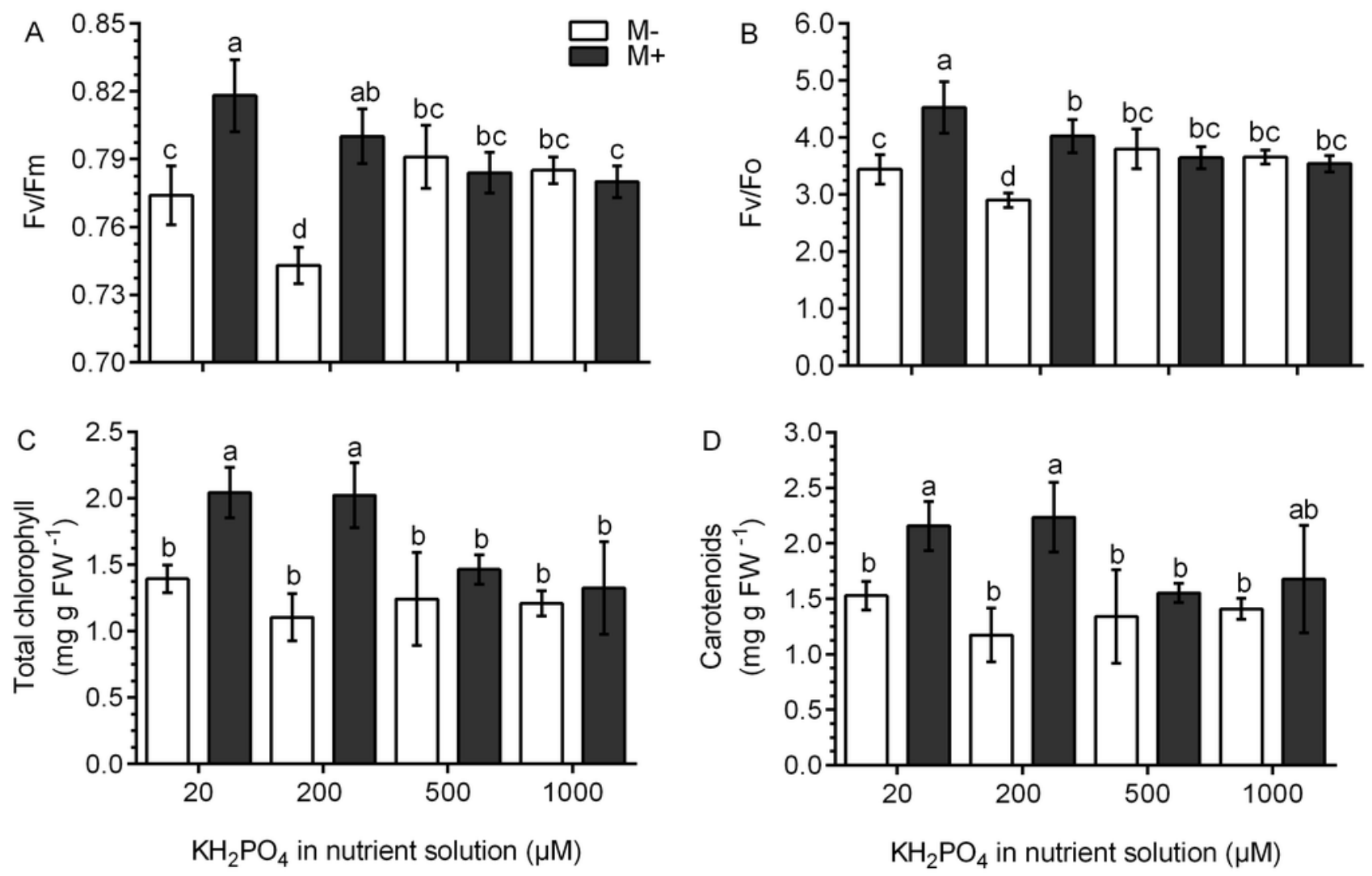


\section{Figure 6}

Figure 6. Differential transcript accumulation of three key genes from the SG biosynthetic pathway under $\mathrm{AM}$ symbiosis and different $\mathrm{KH}_{2} \mathrm{PO}_{4}$ concentrations.

KO (A), UGT74GI (B) and UGT76GI (C) relative expression levels in S. rebaudiana plants that were mycorrhized and fertilized with Hoagland solution at 200 and $1000 \mu \mathrm{M} \mathrm{KH}_{2} \mathrm{PO}_{4}$. For each condition, the transcript levels of the KO, UGT74G1 and UGT76G1 genes were first normalized against SrGAPDH and then normalized against the gene expression of $S$. rebaudiana without inoculation. The analysis of the relative gene expression data used the $2^{-\Delta \Delta C T}$ method. Bars represent the mean \pm standard deviation (SD) of three biological and three technical replicates. Different letters indicate significant differences according to Student's $t$ test $(P<0.05)$. 

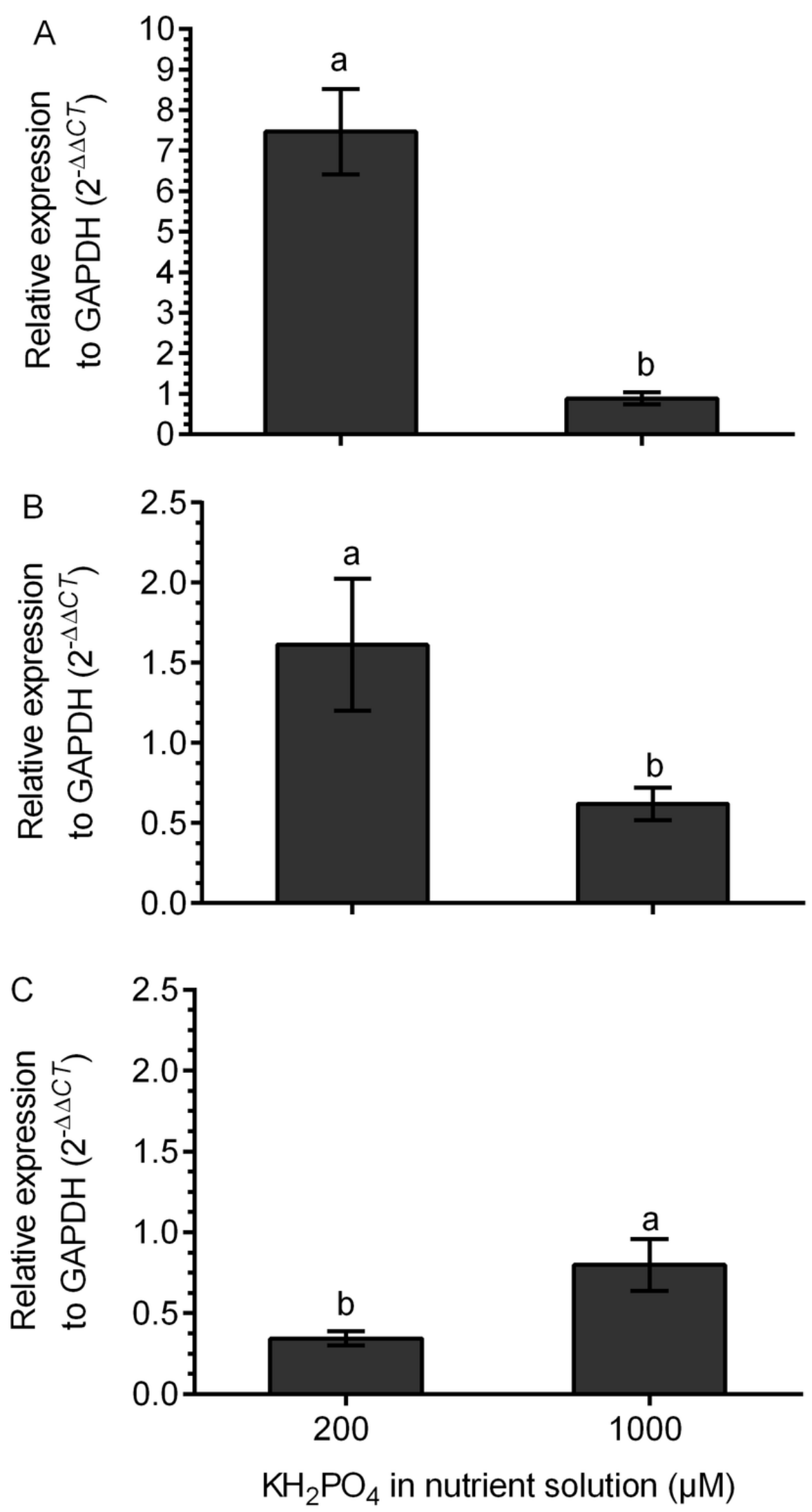


\section{Figure 7}

Figure 7. Quantification of $\mathrm{SG}$ concentration under $\mathrm{AM}$ symbiosis and different $\mathrm{KH}_{2} \mathrm{PO}_{4}$ concentrations.

Stevioside $(A)$ and rebaudioside $A(B)$ concentration in mycorrhiza-colonized $(M+)$ and noncolonized (M-) S. rebaudiana plants fertilized with Hoagland solution at 200 and $1000 \mu \mathrm{M}$ $\mathrm{KH}_{2} \mathrm{PO}_{4}$. Bars represent the mean \pm standard deviation (SD) of six replicates. Different letters indicate significant differences according to Tukey's test $(P<0.05)$. 

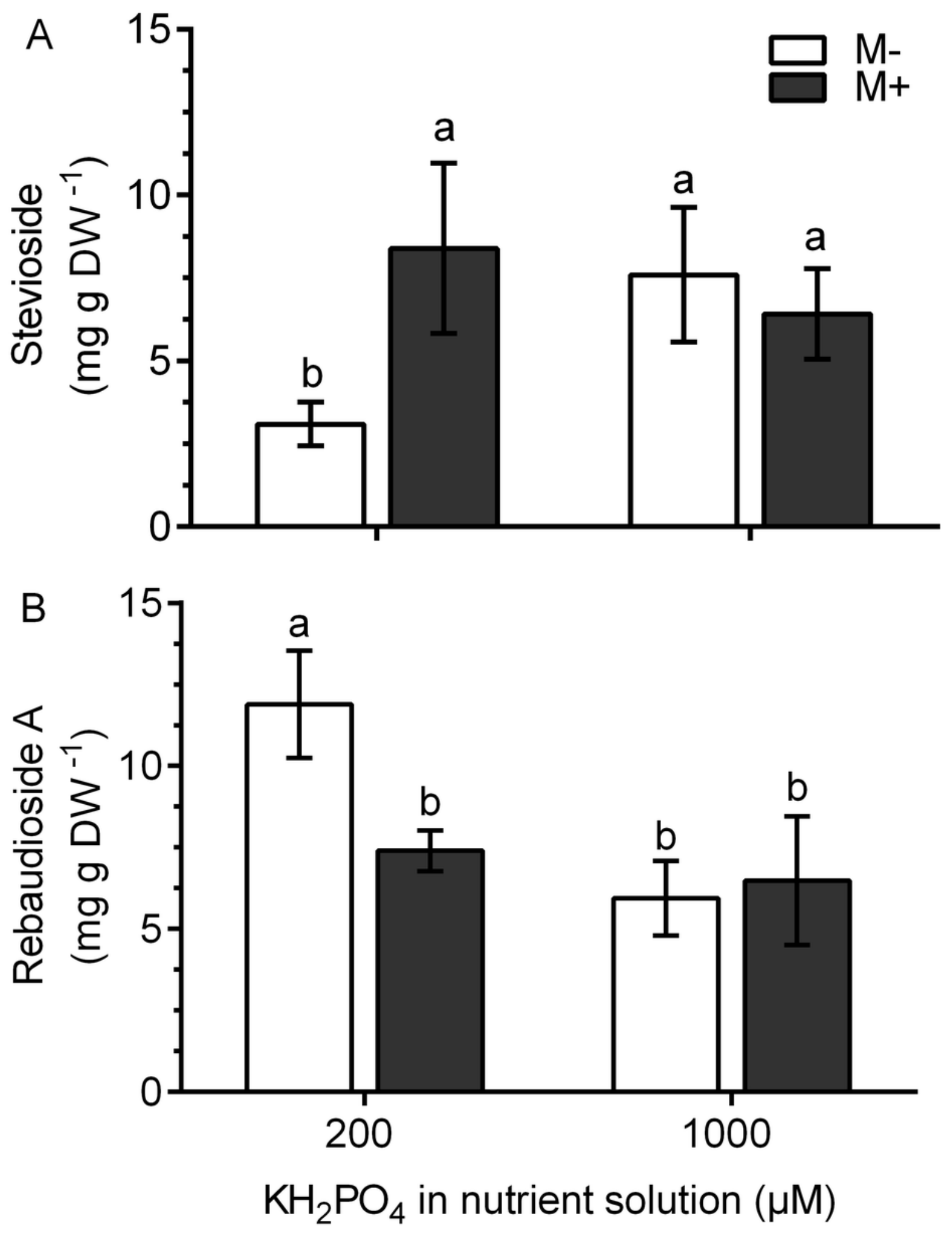